\author{
Federal Reserve Bank of Dallas \\ Globalization and Monetary Policy Institute \\ Working Paper No. 222 \\ http://www.dallasfed.org/assets/documents/institute/wpapers/2015/0222.pdf
}

\title{
Trilemma, Not Dilemma: Financial Globalisation and Monetary Policy Effectiveness*
}

\author{
Georgios Georgiadis \\ European Central Bank \\ Arnaud Mehl \\ European Central Bank
}

January 2015

\begin{abstract}
We investigate whether the classic Mundell-Flemming "trilemma" has morphed into a "dilemma" due to financial globalisation. According to the dilemma hypothesis, global financial cycles determine domestic financial conditions regardless of an economy's exchange rate regime and monetary policy autonomy is possible only if capital mobility is restricted. We find that global financial cycles indeed reduce domestic monetary policy effectiveness in more financially integrated economies. However, we also find that another salient feature of financial globalisation has the opposite effect and amplifies monetary policy effectiveness: Economies increasingly net long in foreign currency experience larger valuation effects on their external balance sheets in response to exchange rate movements triggered by monetary policy impulses. Overall, we find that the net effect of financial globalisation since the 1990s has been to amplify monetary policy effectiveness in the typical advanced and emerging market economy. Specifically, our results suggest that the output effect of a tightening in monetary policy has been stronger by $40 \%$ due to financial globalisation. Insofar as valuation effects can only play out if an economy's exchange rate is flexible, the choice of the exchange rate regime remains critical for monetary policy autonomy under capital mobility and in the presence of global financial cycles. Thus, our results suggest that the classic trilemma remains valid.
\end{abstract}

JEL codes: E52, F30, F41, F62

\footnotetext{
* Georgios Georgiadis, European Central Bank, 60311 Frankfurt am Main, Germany. 49-69-1344-5851. georgios.georgiadis@ecb.int. Arnaud Mehl, European Central Bank, 60311 Frankfurt am Main, Germany. 49-69-1344-8683. arnaud.mehl@ecb.int. We thank Simone Auer, Matthieu Bussiere, Alexander Chudik, Luca Dedola, Charles Engel, Johannes Gräb, Philip Lane, Gianni Lombardo, Paolo Manasse, Frank Moss, Ugo Panizza as well as conference and seminar participants at the Bank for International Settlements, Banque de France, Bundesbank, European Central Bank, the 14th DIW Macroeconometric Workshop on 28 November 2014 and at the conference on "Exchange Rates, Monetary Policy and Financial Stability in Emerging Markets and Developing Countries” on 13 October 2014 for helpful comments and suggestions. We are also grateful to Philip Lane for sharing with us unpublished updated data on net foreign currency exposures. The views in this paper are those of the authors and do not necessarily reflect the views of the European Central Bank, the Federal Reserve Bank of Dallas or the Federal Reserve System.
} 


\section{Introduction}

Standard macroeconomic theory posits that an economy can have at most two out of an open capital account, a fixed exchange rate and an independent monetary policy. Specifically, if capital is allowed to move freely across borders, domestic interest rates can deviate from interest rates abroad only if the exchange rate is flexible. Alternatively, if policy-makers seek to stabilise the exchange rate under free capital mobility, domestic interest rates have to shadow foreign interest rates. This is the classic Mundell-Flemming "trilemma" or "impossible trinity".

The trilemma describes reasonably well the trade-offs between international capital mobility, the choice of the exchange rate regime and monetary policy autonomy over the last century or so (Obstfeld et al., 2005). However, the rise of financial globalisation since the late 1990s has triggered a lively debate as to whether exchange rate flexibility continues to be a sufficient condition for monetary policy autonomy. In particular, evidence suggests that domestic financial conditions are increasingly affected by developments in the rest of the world. This notwithstanding, until the global financial crisis the consensus was that financial globalisation had not materially reduced monetary control (see Yellen, 2006; Bernanke, 2007; Woodford, 2007; Weber, 2008; Kamin, 2010, and references therein).

The debate has intensified after the global financial crisis, which epitomised the role of global financial cycles in interest rates, asset prices, capital flows and bank leverage (Shin, 2012; Rey, 2013; Bruno and Shin, 2014; Agrippino and Rey, 2014). Specifically, it has been argued that financial conditions in the world's foremost financial centre - namely the US - spill over to other economies through global financial cycles regardless of the exchange rate regime and override the efforts of domestic monetary policy to steer financial conditions. Put differently, due to global financial cycles non-US central banks allegedly lose the ability to influence domestic long-term interest rates even in the presence of flexible exchange rates. As a consequence, it is argued, the classic trilemma has morphed into a "dilemma" and the impossible trinity into an "irreconcilable duo": As long as capital is allowed to flow freely across borders, financial globalisation renders monetary policy in non-US economies ineffective, even if their exchange rates are flexible. ${ }^{1,2}$ While this debate has been particularly heated in emerging market economies, it also concerns advanced economies. For instance, when explaining the ECB's decision to adopt forward guidance President Mario Draghi noted that "a tightening of the policy stance may arise from developments in global bond markets that unduly spill over to the interest rate term structure in the euro area. So far our forward guidance has managed to decouple euro area forward curves somewhat from developments in the US" (Draghi, 2014).

\footnotetext{
${ }^{1}$ Interestingly, the evidence also "supports a modified view of the trilemma for the modern [post-Bretton Woods] era. Both the exchange rate regime and capital controls clearly affect autonomy, but the combination of floating with capital controls seems to provide unfettered autonomy, and removing either limits autonomy to some degree" (see Obstfeld et al., 2005, p. 433).

${ }^{2}$ Farhi and Werning (2013) study a small open economy model in which, in contrast with the Mundellian view, capital controls are desirable even when the exchange rate is flexible as they help to smooth capital flows.
} 
However, there is one aspect of financial globalisation which has been under-appreciated in this debate. In particular, along with the growth in the size of external balance sheets associated with financial globalisation economies' net foreign currency exposures have risen as well: Both advanced and emerging market economies have been increasingly net long in foreign currency (see Burger et al., 2010; Hausmann and Panizza, 2011; Benetrix et al., forthcoming; Burger et al., 2014; Hale et al., 2014). And as shown by Meier (2013) by extending Woodford (2007)'s classic analysis, rising net foreign currency exposures imply that valuation effects in response to exchange rate movements become larger and increasingly counteract the weakening of monetary policy effectiveness that results from the loss in domestic interest rate policy autonomy due to global financial cycles. In other words, while financial globalisation might weaken the interest rate channel of monetary policy through global financial cycle effects, it may strengthen the exchange rate channel through net foreign currency exposure effects.

Our paper addresses the questions as to (i) whether global financial cycle and net foreign currency exposure effects have been empirically relevant and, if so, (ii) which of these competing forces has had a stronger impact on domestic monetary policy effectiveness since the 1990s. To answer these questions, we first estimate the response of output to a domestic monetary policy shock for a sample of economies during 1999-2009. We then examine whether heterogeneities in the domestic transmission of monetary policy can be explained by differences in economies' global financial integration patterns. In particular, we consider the role of two salient features of financial globalisation for cross-country asymmetries in monetary policy effectiveness: The size of external balance sheets, which reflects economies' susceptibility to global financial cycle effects; and the currency exposure of economies' external balance sheets, which captures their susceptibility to exchange rate valuation effects.

We focus on euro area economies in the baseline analysis to exploit the fact that they are more similar to each other along a number of dimensions than economies in a broader sample. This reduces the list of country characteristics we need to control for in studying the determinants of asymmetries in monetary policy transmission in a cross-section of economies, which is important as we are working with small samples. For example, while Anglo-Saxon economies tend to have market-based financial systems, banks play a more important role in continental European and emerging market economies, which affects in non-trivial ways the transmission of monetary policy (see Allen, 2004). Similarly, inflation volatility is typically higher in emerging market than in advanced economies, which steepens the Philips curve (see Jarocinski, 2010). Emerging market economies also often manage their currency heavily, which clogs the exchange rate channel of monetary policy transmission. Moreover, due to the euro area's single monetary policy, considering solely euro area economies ensures that the monetary policy shock we identify is truly identical across economies. Similarly, focusing on euro area economies ensures that asymmetries in monetary policy transmission are not driven by differences in the (expected) endogenous response of monetary policy during the transition back to the steady state. In order to ensure that our results are not confined to euro area economies, in extensions of our baseline analysis we 
consider a broader country sample which includes non-euro area advanced and emerging market economies as well.

More specifically, our empirical approach consists of two stages. First, we obtain estimates of the impact of a monetary policy shock on output from a mixed cross-section global VAR (MCSGVAR) model with sign restrictions. A key advantage of this model relative to the standard GVAR model suggested by Pesaran et al. (2004) is that we can include euro area economies individually and, at the same time, model euro area monetary policy as a function of aggregate euro area output growth and inflation. Moreover, the GVAR framework allows us to take into account spillovers from euro area monetary policy to the rest of the world and possible spillbacks, which may have a quantitatively important impact on the effects of monetary policy on domestic variables. In a second stage, we regress the trough responses of output to a monetary policy shock on the overall size of economies' external balance sheets - to capture the impact of global financial cycle effects on monetary policy effectiveness - and of the latters' currency exposure - to capture the impact of net foreign currency exposure effects. In so doing, we control for standard determinants of monetary policy transmission such as labour market rigidities and industry structure.

Our approach differs from that in existing studies on the trilemma (see Philippon et al., 2001; Frankel et al., 2004; Obstfeld et al., 2005; Shambaugh, 2004; Miniane and Rogers, 2007; Bluedorn and Bowdler, 2010; Klein and Shambaugh, 2013; Obstfeld, 2014). Specifically, the extant literature typically seeks to gauge the extent to which domestic interest rates are driven by world/base-country interest rates. To do so, these studies distinguish between floaters and peggers as well as between economies that impose capital controls and those that do not. In general, this literature finds that pass-through from world/base-country to domestic interest rates is stronger in case of exchange rate pegs and when capital flows are unrestricted. In this paper, we do not assess the extent to which domestic financial conditions are determined by monetary policy abroad and whether differences in domestic interest rate policy autonomy are related to economies' financial integration patterns. Instead, we investigate whether domestic monetary policy is less effective - in terms of its impact on output - in economies that are more integrated in global financial markets. Moreover, in addition to global financial cycle effects we account for an additional channel through which financial globalisation can affect domestic monetary policy effectiveness: net foreign currency exposure effects. Our approach is thus more general, and it enables us to test directly whether financial globalisation has reduced - or strengthened-domestic monetary policy effectiveness.

We find empirical support both for global financial cycle and net foreign currency exposure effects on domestic monetary policy effectiveness. On the one hand, economies which are more susceptible to global financial cycle effects display a weaker response of output to monetary policy. On the other hand, economies with larger net foreign currency exposures exhibit a stronger response of output to a monetary policy shock. Applying these estimates from the 
cross-section to the evolution of economies' susceptibility to global financial cycle and net foreign currency exposure effects within economies over time, we find that financial globalisation has not markedly changed monetary policy effectiveness in the euro area since the late 1990s. In contrast, financial globalisation has amplified monetary policy effectiveness in the typical advanced and emerging market economy. Moreover, while the results at the group level hide considerable heterogeneity at the country level for euro area and advanced economies, it appears that financial globalisation has strengthened monetary policy effectiveness in most emerging market economies, in line with their progress in redeeming from the "original sin" in the 2000s.

Taken together, our results do not support the hypothesis that financial globalisation is necessarily associated with a reduction in monetary policy effectiveness in economies with flexible exchange rates. In particular, even if flexible exchange rates do not ensure insulation of domestic financial conditions from global financial cycles, flexible exchange rates support monetary policy effectiveness through net foreign currency exposure effects. Hence, in general flexible exchange rates remain critical to monetary policy autonomy under capital mobility, which implies that the classic trilemma is still valid. Another implication of our results is that even if it does not necessarily reduce its effectiveness, financial globalisation does modify the transmission of monetary policy. In particular, in addition to their impact on inflation pass-through or trade competitiveness, under financial globalisation exchange rate movements triggered by monetary policy impulses affect domestic agents' wealth and, thereby, spending and investment decisions. Financial globalisation may thus imply that the interest rate channel loses and that the exchange rate channel to gains importance. These changes may also have implications for optimal monetary policy and international monetary policy coordination.

The remainder of the paper is organised as follows. Section 2 reviews the mechanisms through which financial globalisation may affect domestic monetary policy transmission. We lay out our modelling strategy in Section 3. Section 4 presents our main results. An array of robustness checks is discussed in Section 5. Finally, Section 6 concludes and draws implications from our findings for policy and future research.

\section{How Can Financial Globalisation Affect Monetary Policy Ef- fectiveness?}

\subsection{Global Financial Cycle Effects}

An important transmission channel of monetary policy operates through long-term interest rates that shape firms' credit-financed investment and households' consumption decisions. According to the expectations hypothesis, long-term interest rates are determined by expected future shortterm rates, which, in turn, are set by an economy's central bank. However, as long-term interest 
rates also include risk premia, financial globalisation may weaken monetary control if domestic risk premia are sensitive to their foreign counterparts. This may be the case if domestic and foreign financial assets are considered as substitutes by investors, and when capital is allowed to move freely and at low cost across borders.

Empirical evidence substantiates the view that risk premia co-move strongly across economies. For example, Hellerstein (2011), Rey (2013) as well as Agrippino and Rey (2014) find that one global factor explains a large fraction of the cross-sectional variance of risky returns around the world. Importantly, Rey (2013) and Agrippino and Rey (2014) find that a major driver of this global factor is US monetary policy. Similarly, Bekaert et al. (2013) as well as Bruno and Shin (2014) provide evidence that US monetary policy has a large impact on global risk aversion. Moreover, Rey (2013), Agrippino and Rey (2014) as well as Bruno and Shin (2014) find that US monetary policy drives the leverage of global banks, which transmits US financial conditions to the rest of the world. ${ }^{3}$ In a related vein, Reinhart and Reinhart (2009), Forbes and Warnock (2012) as well as Ghosh et al. (2014) put forth evidence suggesting that US monetary policy and global risk aversion are key determinants of global capital flow waves that transmit financial conditions in the US across the world. Lo Duca et al. (2014) find that US unconventional monetary policy has been a major determinant of the recent surge in global bond issuance, and the results of McCauley et al. (2014) suggest that US monetary policy has been a crucial driver of the growth in offshore US dollar credit. Obstfeld (2014) finds that even though changes in US short-term interest rates do not have a statistically significant impact on domestic shortterm interest rates in economies with flexible exchange rates, the latter do not insulate domestic long-term interest rates from those in the US; similarly, Ito (2014) finds that the transmission of changes in domestic short-term to long-term rates interest rates is weaker in economies which are more integrated in global financial markets. Finally, Obstfeld (2014) finds that shifts in global risk aversion have a statistically significant impact on non-US long-term interest rates. The evidence thus points to the existence of a global financial cycle which originates in the US and which undermines interest rate autonomy and thereby monetary policy effectiveness in non-center economies. ${ }^{4}$

Given that they operate through cross-border capital flows, the extent to which economies are susceptible to global financial cycles should be related to their degree of integration in global financial markets. The latter is typically measured by the size of economies' external balance sheet. The data on gross foreign asset and liability positions for a large panel of economies' have been assembled by Lane and Milesi-Ferretti $(2001,2007)$. The top panel of Figure 1 shows the change in euro area economies' gross foreign asset and liability positions relative to GDP,

\footnotetext{
${ }^{3}$ Cetorelli and Goldberg (2012) find that globally active US banks respond to local shocks by shifting liquidity through internal funding markets across domestic and foreign subsidiaries, transmitting US monetary policy to the rest of the world. Domestic (both US and non-US) financial conditions hence become less responsive to domestic monetary policy and, at the same time, more responsive to foreign monetary policy.

${ }^{4} \mathrm{He}$ and McCauley (2013) as well as Obstfeld (2014) provide extensive discussions of the channels of transmission from world and US to domestic interest rates and financial conditions more generally.
} 
$g_{\text {fal }}$, during 1999-2009. The bottom panel shows the levels in 2009 (see also Table 1). ${ }^{5}$ There has been considerable variation in gross foreign asset and liability positions over time and across economies. In particular, gross foreign asset and liability positions have increased substantially in most euro area economies during 1999-2009. While Austria, Ireland, Greece, Portugal and Slovenia saw a strong increase in their gross foreign asset and liability positions, Italy and Finland experienced rather small increases. In level terms, while Belgium, Ireland, and the Netherlands have high gross foreign asset and liability positions, they are relatively low in Greece, Italy and Slovenia. This heterogeneity also applies to the world as a whole. Specifically, while the euro area and other advanced economies expanded their gross foreign asset and liability positions strongly during 1999-2009, emerging market economies did so much less. And while euro area economies had large gross foreign asset positions in 2009, they were lower in emerging market economies.

\section{$2.2 \quad$ Net Foreign Currency Exposure Effects}

Differences in the currency composition of an economy's foreign assets and liabilities give rise to valuation effects in response to exchange rate fluctuations. A rigorous analysis of the role of exchange rate valuation effects for domestic monetary policy transmission under financial globalisation is presented in Meier (2013). ${ }^{6}$ Extending the New Keynesian dynamic stochastic general equilibrium (DSGE) model of Woodford (2007), Meier (2013) finds that a contractionary monetary policy shock is associated with a weaker interest rate channel as financial globalisation allows agents to smooth consumption by borrowing from abroad. At the same time, Meier (2013) finds that the appreciation of the domestic currency in response to a tightening in monetary policy is associated with negative wealth effects as the home-currency value of an economy's net foreign asset and liability position declines, at least to the extent that foreign assets (liabilities) are denominated in foreign (domestic) currency. Overall, Meier (2013) argues that for plausible parameter values the weakening of the interest rate channel is outweighed by the strengthening

\footnotetext{
${ }^{5}$ To minimise the influence of extreme values we use $\log \left(1+g f a l_{i t}\right)$ throughout the paper, which we refer to as fal $_{i t}$ for ease of notation.

${ }^{6}$ Financial globalisation, valuation effects and monetary policy have been studied from a theoretical perspective elsewhere as well. For example, Devereux and Sutherland (2008) find that pursuing price stability remains welfare maximising under financial globalisation. Engel and Matsumoto (2009) find that exchange rate movements in the presence of foreign currency exposures have major implications for welfare, risk sharing and the international diversification puzzle (see also the discussion in Engel, 2014). Devereux and Sutherland (2010) study the role of valuation effects for the evolution of net foreign asset positions. Devereux and Yetman (2014) show that trade and financial integration reduce the gains from using sterilised interventions to influence exchange rates. In a somewhat different context, Devereux et al. (2013) analyse the extent to which improved performance in terms of in the level and predictability of inflation across economies has contributed to the rise of financial globalisation. Finally, Tille (2008) studies the role of exchange rate valuation effects for the cross-border transmission of shocks.
} 
of the exchange rate channel. ${ }^{7,8}$ In addition to the wealth effects stemming from changes in the valuation of the stock of foreign assets and liabilities, exchange rate valuation effects triggered by monetary policy impulses may also arise from changes in the home-currency value of foreign investment income flows (see Auer, 2014). Specifically, as dividend payments on foreign equity holdings are typically denominated in foreign currency, an appreciation of the domestic currency in response to a tightening in domestic monetary policy will reduce the home-currency value of foreign investment income flows.

To measure the exposure of economies' external balance sheets to exchange rate fluctuations, we use the data assembled by Lane and Shambaugh (2010); Benetrix et al. (forthcoming). Denote by $n f a l_{i t}$ and $g f a l_{i t}$ economy $i$ 's net and gross foreign asset and liability position relative to GDP. Furthermore, let $E_{i j t}$ denote the logarithm of the nominal bilateral exchange rate of economy $i$ 's currency vis-à-vis that of economy $j$ in period $t$, expressed in terms of units of the domestic currency relative to one unit of the foreign currency. Moreover, denote by $s_{i t}^{A}$ and $s_{i t}^{L}$ the shares of foreign assets and liabilities in economy $i$ 's external balance sheet; and denote by $\omega_{i t}^{A}$ and $\omega_{i t}^{L}$ the shares of economy $i$ 's foreign assets and liabilities which are denominated in foreign currency. Lane and Shambaugh (2010) define economy $i$ 's net foreign currency exposure as

$$
n f x_{i t} \equiv \frac{\partial^{N} n f a l_{i t}}{\partial E_{i 1 t} \cdots \partial E_{1 N t}}=\left(s_{i t}^{A} \cdot \omega_{i t}^{A}-s_{i t}^{L} \cdot \omega_{i t}^{L}\right) \cdot g f a l_{i t} .
$$

The net foreign currency exposure reflects the change in economy $i$ 's net foreign asset and liability position that results from a uniform depreciation of its currency vis-à-vis all foreign currencies. ${ }^{9}$ Specifically, economy $i$ 's net foreign asset and liability position improves with $\omega_{i t}^{A}$ in response to a depreciation as the domestic-currency value of foreign assets rises if these are denominated in foreign currency. Similarly, economy $i$ 's net foreign asset and liability position worsens with $\omega_{i t}^{L}$ in response to a depreciation of the domestic currency as the domestic-currency value of foreign liabilities rises if these are denominated in foreign currency. Thus, a positive value of $n f x_{i t}$ implies that economy $i$ will experience an improvement in its net foreign asset and liability position in response to a depreciation of its currency vis-à-vis all foreign currencies; analogously, a positive value of $n f x_{i t}$ also implies that economy $i$ will experience a worsening in its net foreign asset position in response to an appreciation of its currency vis-à-vis all foreign

\footnotetext{
${ }^{7}$ Meier (2013) also finds that financial globalisation reflected by a reduction in international financial intermediation costs strengthens monetary policy effectiveness. In particular, a contractionary monetary policy shock is again associated with a weakening in the interest rate channel as agents can more easily smooth consumption by borrowing from abroad. At the same time, however, as the domestic currency appreciates more due to the capital flows that underlie consumption smoothing, net exports decline more strongly than in a baseline scenario without financial integration. Overall, the effect of the stronger exchange rate channel again outweighs that of the weaker interest rate channel.

${ }^{8}$ Of course, an economy's overall net foreign currency exposure may hide significant heterogeneities across sectors. For instance, in some emerging market economies the public sector is net long in foreign currency (through foreign reserves holdings) while the private sector is net short in foreign currency. In this case, the wealth effects described above would only play out if there were transfer schemes that redistribute valuation gains/losses from the private to the public sector and vice versa. We let the data speak for themselves regarding whether such (implicit) schemes are in place.

${ }^{9}$ See Appendix B for details.
} 
currencies. Of course, the magnitude of these valuation effects also depends on the (relative) magnitude of foreign asset and liability holdings, and thereby on $s_{i t}^{A}, s_{i t}^{L}$ and $g f a l_{i t}$.

The top panel of Figure 1 shows the change of euro area economies' net foreign currency exposures during 1999-2009. ${ }^{10}$ The bottom panel shows the corresponding levels in 2009; see also Table 1. The data again display substantial variation. Net foreign currency exposures have risen markedly in Ireland, Austria and Belgium, but only little in France, Spain and Germany. Ireland and the Netherlands stand out as economies with particularly high net foreign currency exposures in 2009, while Italy exhibits a rather low value. As all euro area economies' net foreign currency exposures were positive in 2009, their net foreign asset positions worsen in response to an appreciation of the euro, albeit to different degrees. Quantitatively, the data suggest that valuation effects in response to exchange rate fluctuations are economically significant for a number of euro area economies. A 10\% appreciation of the euro vis-à-vis all other currencies results in a 27 percentage points $(0.1 \times 2.69)$ drop in the net foreign asset position (relative to GDP) for Ireland, and a 2.8 percentage points drop for the average euro area economy. Net foreign currency exposures and their evolution over time also differ markedly across the euro area, other advanced and emerging economies. Specifically, euro area economies have experienced a smaller increase in their net foreign currency exposures during 1999-2009 than non-euro area economies. This reflects the fact that a considerable portion of their foreign assets and liabilities has been denominated in euro, consistent with the progress in financial market integration during the first decade of monetary union. ${ }^{11}$ In level terms, non-euro area advanced economies have rather high net foreign currency exposures, much higher than the average euro area and emerging market economy.

\section{Empirical Modelling Strategy}

\subsection{The MCSGVAR Model}

We use a GVAR model for our analysis in order to account for international financial and trade integration in the global economy. Shocks in many economies may have important spillovers to the rest of the world, followed by spillbacks that should be taken into account in order to estimate consistently the transmission of domestic shocks. In particular, we consider the MCSGVAR model of Georgiadis (forthcoming) to estimate the impact of a monetary policy shock on domestic output. A key advantage of this model relative to the standard GVAR model

\footnotetext{
${ }^{10}$ The data of Lane and Shambaugh (2010); Benetrix et al. (forthcoming) do not include Luxembourg.

${ }^{11}$ As an aside, when redenomination risk mounted in the euro area in 2011-2012, this was tantamount to a potentially huge change in the foreign currency position of individual euro area economies. This suggests that addressing such risk through the announcement of modalities for possible Outright Monetary Transactions was important to maintain the ECB's influence on the monetary policy transmission in the euro area economies concerned.
} 
suggested by Pesaran et al. (2004) is that we can consider euro area economies individually and, at the same time, model euro area monetary policy as a function of aggregate output growth and inflation dynamics. For the euro area, the shock we identify is therefore truly identical across economies, and it is ensured that monetary policy behaves identically for all euro area economies during the reversion to the steady state. These are important model features for the purposes of this paper as they reduce the possible sources of asymmetries in the estimates of the effects of monetary policy, which helps to identify the role of global financial cycle and net foreign currency exposure effects given the small samples we are working with.

As in the standard GVAR literature, the MCSGVAR model of Georgiadis (forthcoming) builds on country-specific VARX models

$$
\boldsymbol{x}_{i t}=\boldsymbol{a}_{i}+\sum_{j=1}^{p_{i}} \boldsymbol{\Phi}_{i j} \cdot \boldsymbol{x}_{i, t-j}+\sum_{j=0}^{p_{i}^{*}} \boldsymbol{\Gamma}_{i j} \cdot \boldsymbol{x}_{i, t-j}^{*}+\boldsymbol{u}_{i t}, \quad i=1,2, \ldots, N,
$$

where $\boldsymbol{x}_{i t}$ is a $k_{i} \times 1$ vector of endogenous variables and $\boldsymbol{x}_{i t}^{*}$ is a $k_{i}^{*} \times 1$ vector of averages of the other countries' endogenous variables. In a standard GVAR model, one would let the subscript $i$ refer to individual economies. Moreover, in each individual economy monetary policy would typically be modelled by entering short-term interest rates in the vector of endogenous variables $\boldsymbol{x}_{i t}$. Of course, this does not apply to the euro area economies, which share a single monetary policy.

In contrast to the standard GVAR model, in the MCSGVAR model of Georgiadis (forthcoming) the subscript $i$ may refer to a generic cross-sectional unit rather than only to economies. This allows us to consider the ECB as a separate unit in the MCSGVAR model along euro area (and non-euro area) economies. In particular, in the ECB's model the "foreign" variables $\boldsymbol{x}_{i t}^{*}$ are given by GDP-weighted averages of individual euro area economies' output and inflation dynamics (and, possibly, trade-weighted non-euro area output growth, inflation and financial market dynamics). As a result, euro area monetary policy is modelled as a function of euro area aggregate output growth and inflation dynamics, while euro area economies are included individually in the MCSGVAR model. Non-euro area economies and their monetary policies can be represented together in single VARX models.

More specifically, for the euro area economies the vector of endogenous variables $\boldsymbol{x}_{i t}$ comprises output and prices. ${ }^{12}$ The corresponding vector of "foreign" variables $\boldsymbol{x}_{i t}^{*}$ includes trade-weighted foreign output, prices and non-euro area short-term interest rates; oil prices; and euro area shortterm interest rates as the ECB is modelled as a distinct unit. As in Pesaran et al. (2004), bilateral exchange rates are not included in each country VARX model symmetrically. In particular, as

\footnotetext{
${ }^{12}$ The sample of euro area economies includes Austria, Belgium, Finland, France, Germany, Greece, Ireland, Italy, Luxembourg, the Netherlands, Portugal and Spain. Slovenia, Slovakia and Estonia are not treated as euro area economies in the estimation of the MCSGVAR model because they joined the euro area at a later stage relative to other members.
} 
all euro area members have the same nominal bilateral exchange rate, we cannot include it as an endogenous variable in each euro area economy model. Instead, we choose the euro as the numéraire and enter the trade-weighted nominal bilateral euro exchange rate in the vector of foreign variables. For the euro area economies we thus have:

$$
\boldsymbol{x}_{i t}=\left[\begin{array}{c}
\text { output } \\
\text { prices }
\end{array}\right], \quad \boldsymbol{x}_{i t}^{*}=\left[\begin{array}{c}
\text { foreign output } \\
\text { foreign prices } \\
\text { euro area short-term interest rates } \\
\text { foreign short-term interest rates } \\
\text { oil prices } \\
\text { exchange rate }
\end{array}\right] .
$$

As discussed above, in order to model euro area monetary policy as a function of euro area aggregate output growth and inflation dynamics - while considering euro area economies individually we introduce the ECB as a separate cross-sectional unit. The short-term interest rate is the only endogenous variable in the ECB's model and the vector of "foreign" variables comprises GDPweighted euro area output and prices. Moreover, the ECB's model also includes GDP-weighted non-euro area short-term interest rates, the euro area trade-weighted nominal exchange rate and oil prices. Specifically:

$$
\left.\boldsymbol{x}_{i t}=\text { [euro area short-term interest rates }\right], \quad \boldsymbol{x}_{i t}^{*}=\left[\begin{array}{c}
\text { euro area output } \\
\text { euro area prices } \\
\text { foreign short-term interest rates } \\
\text { oil prices } \\
\text { exchange rate }
\end{array}\right] \text {. }
$$

For non-euro area economies, the vector of endogenous variables comprises output, prices, the nominal bilateral exchange rate vis-à-vis the euro, and short-term interest rates. The corresponding vector of foreign variables includes trade-weighted foreign output, prices, short-term interest rates and oil prices. Hence, we have:

$$
\boldsymbol{x}_{i t}=\left[\begin{array}{c}
\text { output } \\
\text { prices } \\
\text { short-term interest rates } \\
\text { exchange rate }
\end{array}\right], \quad \boldsymbol{x}_{i t}^{*}=\left[\begin{array}{c}
\text { foreign output } \\
\text { foreign prices } \\
\text { foreign short-term interest rates } \\
\text { oil prices }
\end{array}\right] \text {. }
$$

Finally, as in Georgiadis (forthcoming) we introduce an oil block as an additional cross-sectional unit in order to model the evolution of commodity prices endogenously as a function of global 
output growth, inflation and interest rate developments. Specifically, we have:

$$
\boldsymbol{x}_{i t}=[\text { oil prices }], \quad \boldsymbol{x}_{i t}^{*}=\left[\begin{array}{c}
\text { foreign short-term interest rates } \\
\text { foreign output } \\
\text { foreign prices }
\end{array}\right] .
$$

The derivation of the global solution of the model is standard and can be found in Appendix A.

\subsection{Model Specification}

We enter output, prices, the nominal bilateral exchange rate and oil prices in first-differences of their logarithms. In order to mitigate the impact of unusual interest rate spikes, we consider $r_{i t}=\log \left(1+R_{i t}\right)$, where $R_{i t}$ is the annual nominal short-term rate, as in Pesaran et al. (2004); we also enter $r_{i t}$ in first-differences. ${ }^{13}$ As in Pesaran et al. (2004), due to the relatively small time-series dimension of our sample, we allow the lag orders of the endogenous and the foreign variables in each VARX model to be at most one. Finally, we treat the US as a dominant unit in the sense of Chudik and Pesaran (2013) to account for the extraordinary role of the US in the global economy. In terms of model specification, this requires to add the domestic endogenous variables of the US in all other units' vectors of foreign variables $\boldsymbol{x}_{i t}^{*}$ in Equations (3) to (6). Georgiadis (forthcoming) shows that estimates of the effect of a monetary policy shock are robust to a number of alternative model specifications, such as the inclusion of equity prices and the VIX index as endogenous and foreign variables; the treatment of the ECB as a dominant unit alongside the US; extending the sample to 2012; and allowing for higher lag orders in the endogenous variables.

\subsection{Estimation Sample}

Our sample comprises quarterly observations between 1999:Q1 and 2009:Q4 for 61 economies (Table 2). We subsume the economies of Estonia, Latvia and Lithuania into a Baltic (BAL) block, and the economies of Venezuela, Ecuador and Saudi Arabia into an oil exporting countries (OPC) block (the latter should not be confused with the oil block discussed above, which models the evolution of oil prices). We drop the more recent quarters in order to preclude possible structural breaks stemming from the European sovereign debt crisis. All the data we use are taken from Haver Analytics (see Table 3).

\footnotetext{
${ }^{13}$ See Georgiadis (forthcoming) for a discussion of estimating the GVAR in first differences.
} 


\subsection{Identification of Monetary Policy Shocks}

As in Georgiadis (forthcoming) we identify a monetary policy shock by imposing sign restrictions on the responses of short-term interest rates, inflation and the nominal effective exchange rate of the euro. In particular, we require that short-term interest rates rise on impact, that the euro appreciates on impact, and that inflation turns negative after four quarters reflecting the stickiness of aggregate prices; we impose these restrictions on euro area short-term interest rates in the ECB's model, GDP-weighted aggregate euro area inflation, and the trade-weighted nominal effective exchange rate. In Georgiadis (forthcoming) it is shown that estimates of monetary policy transmission are very similar if the monetary policy shock is identified using alternative schemes, such as imposing additional sign restrictions on the responses of output, money growth, and oil price inflation; identifying shocks using the difference between lagged financial market expectations and actual policy rates; and using a monetary policy shock time series obtained from estimated DSGE models such as the New Area-Wide Model of Christoffel et al. (2008) or the model of Smets and Wouters (2003) as an exogenous variable.

\section{Results}

\subsection{Euro Area Sample}

Figure 2 shows the trough responses of the level of real GDP to a 100 basis points surprise increase in euro area short-term interest rates as estimated by the MCSGVAR model with sign restrictions. Belgium, France and Portugal experience a relatively small decline in output; in contrast, output drops strongly in Finland, Ireland, and Slovenia.

To what extent can cross-country asymmetries in the output responses to a monetary policy shock be accounted for by differences in euro area economies' susceptibility to global financial cycle (as proxied by $g f a l_{i t}$ ) and net foreign currency exposure effects (as proxied by $n f x_{i t}$ )? Figure 3 presents scatter plots of $g f a l_{i}$ and $n f x_{i}$ one the one hand and the trough responses of real GDP on the other hand. The scatterplots suggest that the trough responses of real GDP might indeed be positively related to $g f a l_{i}$ and negatively to $n f x_{i}$; however, either the relationship is not statistically significant, and/or some economies appear to be outliers. Of course, these are only unconditional correlations, and the outliers may disappear after additional controls are taken into account.

In particular, we estimate a cross-sectional regression for the determinants of asymmetries in monetary policy transmission in the spirit of Carlino and DeFina (1998) as well as Dedola and Lippi (2005):

$$
s_{i}=\alpha+\gamma \cdot \boldsymbol{w}_{i}+\beta^{g f a l} \cdot g f a l_{i}+\beta^{n f x} \cdot n f x_{i}+u_{i},
$$


where $s_{i}$ is the trough response of real GDP shown in Figure 2 and $\boldsymbol{w}_{i}$ includes standard determinants of monetary policy transmission, such as industry structure and labour market rigidities (see Georgiadis, forthcoming). The data for the explanatory variables are time averages during 1999-2009. ${ }^{14}$ Table 4 reports descriptive statistics for the dependent and the explanatory variables. Note that the trough responses $s_{i}$ have a negative sign as output falls in response to a contractionary monetary policy shock. Thus, based on the discussion in Section 2 we expect $\widehat{\beta}^{g f a l}>0$ if global financial cycle effects reduce monetary policy effectiveness, and $\widehat{\beta}^{n f x}<0$ if net foreign currency exposure effects strengthen monetary policy effectiveness.

As in Georgiadis (forthcoming) the results in Table 5 suggest that labour market rigidities as well as industry structure have a statistically significant impact on monetary policy effectiveness. Moreover, when entered simultaneously in the regression both $g f a l_{i t}$ and $n f x_{i t}$ have a statistically significant impact on monetary policy transmission. This is remarkable insofar as one would expect that the relatively small number of observations would be associated with low power and thus render it more difficult to obtain statistically significant estimates. ${ }^{15}$ In line with the discussion in Section 2, the results suggest that global financial cycle effects weaken monetary policy effectiveness $\left(\widehat{\beta}^{\text {fal }}>0\right)$; also in line with the discussion in Section 2 , the results suggest that net foreign currency exposure effects amplify the impact of monetary policy on output $\left(\widehat{\beta}^{n f x}<0\right)$. Moreover, the results in Table 5 imply that the global financial cycle and exchange rate valuation effects are economically significant. Specifically, a one-standard deviation increase in $n f x_{i}$ is associated with an additional fall in output of 9 basis points in response to a monetary policy tightening $(.43 \times-.21)$; this is sizeable, as the mean trough response of output across euro area economies is 23 basis points. Similarly, a one-standard deviation increase in $g \mathrm{fal}_{i}$ is associated with an additional fall in output of 7 basis points in response to a tightening of monetary policy $(.57 \times .13)$.

Our results thus imply that the impact of financial globalisation on monetary policy transmission is a priori ambiguous. Specifically, whether financial globalisation amplifies or weakens monetary policy transmission depends on the relative magnitude of global financial cycle and net foreign currency exposure effects. To shed light on which of these competing forces has had a bigger impact on monetary policy effectiveness in the euro area since the 1990s, we calculate the actual cumulated partial effects of $g f a l_{i}$ and $n f x_{i}$ over time within economies implied by the estimation results for Equation (7). Specifically, based on the first difference of a panel version of Equation (7) we determine by how much changes in $g f a l_{i t}$ and $n f x_{i t}$ have altered the effect of monetary

\footnotetext{
${ }^{14}$ See Appendix $\mathrm{C}$ for a description of the construction of the indicators of labor market rigidities and industry structure.

${ }^{15}$ In Section 5 we carry out extensive robustness checks to show that our results are not driven by the relatively small number of degrees of freedom in the regression.
} 
policy on output over time within economies according to

$$
\begin{aligned}
\Delta s_{i t}^{g f a l} & \equiv \sum_{j=1}^{t} \widehat{\beta}^{g f a l} \cdot \Delta g f a l_{i j} \\
\Delta s_{i t}^{n f x} & \equiv \sum_{j=1}^{t} \widehat{\beta}^{n f x} \cdot \Delta n f x_{i j} .
\end{aligned}
$$

Given the negative sign of the trough responses of output in response to a monetary policy shock $s_{i}$, the positive sign of the estimate $\widehat{\beta}^{g f a l}$ and the definition of $g f a l_{i}$, a positive value for $\Delta_{i t}^{g f a l}$ implies that monetary policy transmission has weakened due to global financial cycle effects. Analogously, a negative value for $\Delta_{i t}^{n f x}$ implies a strengthening of monetary policy transmission due to net foreign currency exposure effects. To facilitate the comparison of the magnitudes of the two effects, in the following we reverse the sign of $\Delta_{i t}^{n f x}$ : positive values reflect a strengthening of the impact of monetary policy on output.

The upper left-hand side panel of Figure 4 shows the GDP-weighted averages of the cumulation of Equations (8) and (9) across euro area economies during 1999-2012. ${ }^{16}$ The lower left-hand side panel depicts the sum of the cumulated global financial cycle and net foreign currency exposure effects from Equations (8) and (9), taking into account the estimation uncertainty in the regression of Equation (7). The results suggest that financial globalisation has had a dampening effect on monetary policy transmission in the euro area, as global financial cycle effects have outweighed net foreign currency exposure effects. In particular, the results suggest that for the typical euro area economy financial globalisation has reduced the trough response of output to a contractionary monetary policy shock by around 1 basis point in absolute terms, which, however, is little relative to the mean trough response across euro area economies during 1999-2009 (see Table 4). Therefore, while our results for the euro area are qualitatively consistent with the dilemma hypothesis, quantitatively they are far from suggesting that financial globalisation has annihilated monetary policy effectiveness.

It is noteworthy that this finding for the euro area as a whole does not apply homogenously across individual economies. In particular, the top left-hand side panel in Figure 5 plots the change in $g f a l_{i t}$ against that in $n f x_{i t}$ during 1999-2012 for each euro area economy; it also plots the change in monetary policy transmission due to global financial cycle effects against that due to net foreign currency exposure effects in the top right-hand side panel. In the left-hand side panel, the shaded areas indicate the combinations of changes in $g f a l_{i t}$ and $n f x_{i t}$ for which the cumulated global financial cycle and the net foreign currency exposure effects cancel each other out, given the estimates $\widehat{\beta}^{g f a l}$ and $\widehat{\beta}^{n f x}$ in Equation (7); similarly, in the right-hand side panel the shaded areas are separated by the 45-degree line, which indicates for which economies global financial cycle effects have outweighed net foreign currency exposure effects and vice versa. In

\footnotetext{
${ }^{16}$ The country-specific time series for $g f a l_{i}$ and $n f x_{i}$ are smoothed by a Hodrick-Prescott filter before they are used to obtain the results presented in Equations (8) and (9). Results based on country-medians are very similar.
} 
about half of the euro area economies, changes in monetary policy transmission due to global financial cycle effects have dominated those due to net foreign currency exposure effects and vice versa.

\subsection{Non-Euro Area Economies}

The middle and the right-hand side panels of Figure 4 display the change in monetary policy effectiveness due to global financial cycle and net foreign currency exposure effects for a broad set of advanced and major emerging market economies (excluding the US and China) based on the estimates reported in Table 5. ${ }^{17,18}$ The results suggest that for the typical advanced and major emerging market economy the changes in monetary policy transmission due to net foreign currency exposure effects have dominated those due to global financial cycle effects. The change in monetary policy effectiveness due to financial globalisation is also economically significant: An additional fall in output by 4 basis points represents a strengthening of monetary policy effectiveness by about 40\% (see Tables 6 and 7). Financial globalisation has thus strengthened domestic monetary policy effectiveness appreciably for the typical advanced and emerging market economy, which is inconsistent with the dilemma hypothesis.

Interestingly, while the results at the group level hide substantial heterogeneity at the country level for advanced economies, the impact of financial globalisation on monetary policy effectiveness has been rather homogenous across emerging market economies (see Figure 5). In particular, monetary policy effectiveness has strengthened only in about half of the advanced economies. In contrast, in most emerging market economies net foreign currency exposure effects have dominated global financial cycle effects.

As the data on gross foreign asset and liability positions are available prior to 1999, we can calculate the cumulated partial effects of the global financial cycle and net foreign currency exposure effects on changes in domestic monetary policy transmission according to Equations (8) and (9) already from the early 1990s. ${ }^{19}$ The results displayed in Figure 6 are consistent with our findings for 1999-2012, but provide additional insights. In particular, the strengthening of monetary policy effectiveness due to financial globalisation in advanced economies has been a persistent phenomenon and did not start only in 1999. In contrast, financial globalisation has amplified monetary policy transmission in emerging market economies only from the early

\footnotetext{
${ }^{17}$ Specifically, we obtain the estimates of the domestic impact of a monetary policy shocks for these economies by imposing the same sign restrictions as for the euro area. The summary statistics for the data for non-euro area economies are reported in Tables 6 and 7.

${ }^{18}$ Between 1999 and 2009 the renminbi had a strict (crawling) peg to the US dollar. Therefore, China's economy would not have experienced a loss in the home-currency value of its foreign assets denominated in foreign currency in response to a domestic contractionary monetary policy shock that leads to an appreciation of the renminbi. Moreover, as China's capital account has been essentially closed its domestic financial markets should not have been subject to global financial cycles. The results for samples including China are similar.

${ }^{19}$ We do not consider euro area economies due to the structural break elicited by the introduction of the euro in 1999.
} 
2000s onwards. This is consistent with the rise in net foreign currency exposures after the Asian financial crisis, as emerging markets economies have increasingly issued foreign debt in domestic currency, hence redeeming from "original sin", as also discussed in Burger et al. (2010), Hausmann and Panizza (2011), Benetrix et al. (forthcoming), Burger et al. (2014) as well as Hale et al. (2014). Considering the impact of financial globalisation on monetary policy effectiveness over a longer time period thus provides even more evidence which is inconsistent with the dilemma hypothesis.

\section{Sensitivity Analysis}

We consider various robustness checks. First, we investigate alternative measures of economies' susceptibility to global financial cycle and net foreign currency exposure effects. ${ }^{20}$ Second, we consider the sensitivity of our results to the small size of our baseline sample restricted to euro area economies. Finally, we explore the sensitivity of our results to the inclusion of additional control variables in Equation (7).

\subsection{Alternative Measures of Economies' Susceptibility to Global Financial Cycle and Net Foreign Currency Exposure Effects}

\subsubsection{Exchange-Rate Response-Weighted Net Foreign Currency Exposure}

Figure 7 shows that the exchange rate responses to a euro area monetary policy shock differ across currencies. This finding suggests that our baseline measure of net foreign currency exposure might not be fully appropriate, as it reflects the change in the net foreign asset and liability position that occurs in response to a uniform change in an economy's exchange rate of the domestic currency vis-à-vis all foreign currencies. For example, suppose that Portugal's foreign assets were all denominated in sterling and that its foreign liabilities were all denominated in euro; also assume that the euro's exchange rate vis-à-vis sterling did not respond to a euro area monetary policy shock, while the exchange rates vis-à-vis other currencies did. In this case, although Portugal's net foreign currency exposure as defined in Equation (1) would clearly not be nil, exchange rate movements in response to a euro area monetary policy shock would not elicit valuation effects on its external balance sheet.

In order to address this issue we construct a measure of net foreign currency exposure which takes into account the fact that some exchange rates respond more strongly to a euro area

\footnotetext{
${ }^{20}$ We do not consider de jure measures of financial openness such as the one constructed by Chinn and Ito (2003), as these assume the same values across euro area economies due to their membership in the European Union.
} 
monetary policy shock than others, thereby eliciting larger valuation effects. In particular, recall the definition of the net foreign currency exposure in Equation (1)

$$
\begin{aligned}
n f x_{i t} & =\left(s_{i t}^{A} \cdot \omega_{i t}^{A}-s_{i t}^{L} \cdot \omega_{i t}^{L}\right) \cdot g f a l_{i t} \\
& =\left[s_{i t}^{A} \cdot \sum_{j=1, j \neq i}^{N} \omega_{i j t}^{A}-s_{i t}^{L} \cdot \sum_{j=1, j \neq i}^{N} \omega_{i j t}^{L}\right] \cdot g f a l_{i t},
\end{aligned}
$$

where $j$ represents currencies other than the euro. Building on this, we define

$$
\widetilde{n f x_{i t}}=\frac{1}{\sum_{j=1, j \neq i}^{N} i r f_{j}^{f x}}\left[s_{i t}^{A} \cdot \sum_{j=1, j \neq i}^{N} \omega_{i j t}^{A} \cdot i r f_{j}^{f x}-s_{i t}^{L} \cdot \sum_{j=1, j \neq i}^{N} \omega_{i j t}^{L} \cdot i r f_{j}^{f x}\right] \cdot g f a l_{i t},
$$

where $i r f_{j}^{f x}$ represents the maximum appreciation of the euro vis-à-vis currency $j$ in response to a euro area monetary policy shock displayed in Figure 7. According to this measure of net foreign currency exposure, currencies against which the euro exhibits a stronger appreciation in response to a monetary policy tightening enter with a larger weight. The results from using this measure of net foreign currency exposure in the regression of Equation (7) are reported in Table 8 and suggest that our conclusions concerning the impact of financial globalisation on monetary policy effectiveness are unchanged..$^{21,22}$

\subsubsection{Intra-Euro Area Gross Foreign Asset and Liability Positions}

The data on foreign asset and liability positions from Lane and Milesi-Ferretti (2001, 2007) that we use in our baseline specification include intra-euro area holdings. As a consequence, these data might overstate euro area economies' integration into global financial markets, and thereby also their susceptibility to global financial cycle effects. This may be innocuous for the results obtained for euro area economies shown in Figures 4 and 5 , as the upward bias in $g f_{a l}$ should be compensated by a downward bias in $\widehat{\beta}^{\text {gfal }}$ in Equation (7). However, the downward bias in $\widehat{\beta}^{g f a l}$ would imply that the global financial cycle effects displayed in Figures 4 and 5 would be underestimated for non-euro area economies, as their data for $\mathrm{gfal}_{i}$ are not inflated by intra-currency area foreign asset and liability holdings.

In order to ensure that our results for non-euro area economies are not biased due to intra-euro area holdings, we use data on bilateral foreign asset and liability positions which allows us to identify extra-euro area holdings: the IMF's Coordinated Portfolio Investment Survey (CPIS)

\footnotetext{
${ }^{21}$ The reason for this result is that there is not much heterogeneity in the currency composition of euro area economies' foreign assets. For all euro area economies almost all foreign currency-denominated foreign assets are in US dollars.

${ }^{22}$ We do not calculate this alternative measure of net foreign currency exposure for Slovenia as it maintained a flexible exchange rate vis-à-vis the euro for half of the sample period.
} 
data in the regression of Equation (7). ${ }^{23}$ Table 8 shows that our baseline results are hardly changed if we replace the gross foreign asset and liability positions from Lane and Milesi-Ferretti (2001, 2007) by those from the CPIS data. Moreover, Figure 8 shows that our baseline results for the changes in monetary policy effectiveness due to global financial cycle and net foreign currency exposure effects for non-euro area advanced and emerging market economies are unchanged as well. In contrast to our baseline results, however, using the CPIS data suggests that financial globalisation has strengthened rather than weakened monetary policy effectiveness in the euro area. Hence, accounting for intra-euro area foreign asset and liability holdings produces evidence which is inconsistent with the dilemma hypothesis for all country groups.

\subsubsection{BIS Data on Cross-Border Banking Claims}

Instead of the gross foreign asset and liability positions from Lane and Milesi-Ferretti (2001, 2007) we next consider the sum of euro area economies' banking claims on non-euro area economies as well as non-euro area claims on euro area economies. As in the case of the CPIS data, the BIS data allow us to construct measures of cross-border exposures that do not include intra-euro area holdings. Table 8 reports the results from the estimation of Equation (7) using this alternative measure of economies' susceptibility to global financial cycle effects. As in the baseline results, the coefficient estimate for the net foreign currency exposure has a negative sign and is statistically significant. Even though the coefficient estimate for gross banking claims has a positive sign, it is not statistically significant. The evidence based on extra-euro area cross-border banking claims is therefore also inconsistent with the dilemma hypothesis.

\subsubsection{Gross Foreign Asset and Liability Positions relative to Domestic Credit}

Whether global financial cycles can affect domestic financial conditions might also hinge on the the size of an economy's external balance sheet relative to that of its domestic financial markets. We therefore consider the ratio of the gross foreign asset and liability position to domestic credit provided by the banking sector. ${ }^{24}$ As in the baseline results, the coefficient estimate for the net foreign currency exposure reported in Table 8 has a negative sign and is statistically significant. The coefficient estimate for gross foreign assets and liabilities relative to domestic credit has a positive sign and is - marginally - statistically significant. Thus, the results are in line with those from the baseline.

\footnotetext{
${ }^{23}$ The CPIS data report bilateral asset and liability positions for around 70 investor and over 200 destination economies for the time period from 2001 to 2012. We do not consider these data in the baseline because they are subject to several serious - and well-known - drawbacks (see Lane and Milesi-Ferretti, 2008). For example, some major economies such as China do not participate in the survey; moreover, observations are available only since 2002.

${ }^{24}$ The data are taken from from the World Bank's World Development Indicators.
} 


\subsubsection{Gross Foreign Asset and Liability Buckets}

The distribution of gross foreign asset and liability positions is skewed, as a few euro area economies exhibit very high values. One way to ensure that our results are not driven by extreme observations is to allocate economies into buckets that reflect groups of economies with different, discrete degrees of susceptibility to global financial cycle effects. Specifically, we allocate euro area economies into four buckets defined by the $25 \%, 50 \%$ and $75 \%$ percentiles of the cross-country distribution of gross foreign asset and liability positions. As shown in Table 8 , the results are again in line with those from the baseline.

\subsubsection{Price-Based Measure of Global Financial Integration}

Table 8 also reports the results obtained from replacing the gross foreign asset and liability position by the correlation between euro area economies' and world equity returns as a measure for financial market integration in the spirit of Quinn and Voth (2008). The coefficient estimate for the net foreign currency exposure is again negative and statistically significant, in line with our baseline results. In contrast, while the coefficient estimate for the return correlation is positive, it is not statistically significant. The results from this robustness check are therefore inconsistent with the dilemma hypothesis.

\subsubsection{Share of US/UK-Owned Banks}

We next consider the share of US and UK-owned banks in the domestic economy (a proxy for the importance of global banks in the domestic financial system) as an alternative measure of economies' susceptibility to global financial cycle effects. For example, Goldberg (2013) finds that domestic interest rates co-move more strongly with those in the base economy even in the presence of flexible exchange rates if a larger share of domestic credit is provided by global banks. Using the bank ownership data compiled by Claessens and Horen (2014), the results reported in Table 8 are again very similar to our baseline findings.

\subsubsection{Principle Component of Alternative Measures}

Finally, Table 8 shows that the results are once again very similar if we take the principal component of all the aforementioned alternative measures of economies' susceptibility to global financial cycle effects. 


\subsection{Sample Size and Outliers}

\subsubsection{Robust and Median Regressions}

We first obtain robust-to-outlier (rreg) and median (qreg) regression estimates. The outcome is reported in Table 9, and suggests that even if the robust estimator estimator identifies Ireland as an outlier and drops it from the regression, the results are unchanged. Similarly, the results are also unchanged when carrying out median regressions.

\subsubsection{Outliers and Additional Euro Area Economies}

Table 9 also suggests that our results are unchanged if we drop Ireland, Ireland and Belgium together (due to their large values for $g f a l_{i}$ and/or $n f x_{i}$ ) or Slovenia (as it joined the euro area only in 2007). Finally, our results are also unchanged if we add Slovakia - which adopted the euro only in 2009- to our baseline sample.

\subsubsection{Principal Component of Traditional Determinants}

One might fear that our findings could be statistical artifacts as we enter five explanatory variables (including the intercept) in our baseline regression for which we have only twelve observations. In particular, by including as many (mutually orthogonal) regressors as there are observations, one can perfectly replicate the dependent variable even if there is no structural relationship between the explanatory and the dependent variables. To alleviate such concerns we reduce the number of regressors by replacing labor market rigidities and industry structure by their first principal component; readers should note that in the baseline we consider these variables as controls whose role in monetary policy transmission is not of particular interest to this paper. The results reported in Table 9 are again similar to those from the baseline. ${ }^{25}$

\subsubsection{Considering only $g f a l_{i}$ and $n f x_{i}$}

The results reported in Table 9 suggest that even if we increase the number of degrees of freedom further by including only $g f a l_{i}$ and $n f x_{i}$ as explanatory variables, the results are similar to those from the baseline.

\footnotetext{
${ }^{25}$ Notice also that the regressors we include are not mutually orthogonal; in fact, gross foreign asset and liabilities and net foreign currency exposures are strongly positively correlated.
} 


\subsubsection{Broad Country Sample}

We focus on a small euro area sample in the baseline because expanding the sample is likely to introduce substantial cross-country heterogeneity in Equation (7) which would have to be accounted for by additional controls, which is not straightforward given the small number of observations available. However, examining the results for an expanded sample with non-euro area economies is important for two reasons. First, despite the issue of increasing heterogeneity it may serve as a useful robustness check to the small number of degrees of freedom. Second, as we determine the impact of financial globalisation on monetary policy effectiveness for non-euro area economies in Section 4.2, it is important to check that the data provide evidence for global financial cycle and net foreign currency exposure effects for these economies as well. Therefore, in this robustness check we consider a broad country sample with a number of additional noneuro area advanced and emerging market economies. As net foreign currency exposure effects can only affect monetary policy effectiveness if the exchange rate is flexible, we only consider economies which have a de facto crawling band or more flexible exchange rate regime according to the classification of Ilzetzki et al. (2010). ${ }^{26}$ The first column of Table 10 reports the results from estimating Equation (7) if we consider all euro area and non-euro area economies without adding additional controls. Only the coefficient estimate for industry structure retains its negative sign and statistical significance; moreover, the coefficient estimate for $g f_{a l} l_{i}$ turns negative, which is inconsistent with the dilemma hypothesis. However, once we a add a few controls to account for the increasing degree of cross-country heterogeneity in this broader sample our baseline results are essentially recovered. ${ }^{27}$ Note that while the coefficient estimates from the broader country sample have the same sign as those in the baseline, they have smaller values in absolute terms. However, as shown in Figures 9 and 10 this does not have a large impact on the change in monetary policy effectiveness due to the global financial cycle and net foreign currency exposure effects over time. ${ }^{28}$

\subsection{Additional Controls}

\subsubsection{Trade Integration}

It could also be argued that our estimation results for $\mathrm{gfal}_{i}$ pick up the effect of trade integration on monetary policy transmission. Indeed, Cwik et al. (2011) show in a DSGE model that trade integration may amplify domestic monetary policy transmission. Moreover, trade integration

\footnotetext{
${ }^{26}$ Insofar as the euro is a floating exchange rate, the exchange rate regime of the euro area economies - from an external perspective - is classified as a float.

${ }^{27}$ The euro area dummy may capture biases arising from the fact that the gross foreign asset and liability positions for the euro area include intra-euro area holdings, and also that euro area economies maintain a stable nominal exchange rate vis-à-vis their main trading partners. The euro area contiguity dummy may capture the strong trade and financial ties of these economies with the euro area.

${ }^{28}$ The results are very similar if we consider only advanced economies.
} 
is positively correlated with financial integration in the data. However, it is unlikely that our findings are biased because trade integration is omitted as an explanatory variable. In line with the prediction of Cwik et al. (2011), the results reported in Table 11 document that the coefficient estimate for trade integration is negative and-marginally - statistically significant. At the same time, however, the coefficient estimates for $g f a l_{i}$ and $n f x_{i}$ are very similar to those from our baseline results.

\subsubsection{Domestic Financial Market Development}

One could also argue that $g f a l_{i}$ and $n f x_{i}$ pick up the effect of financial market development on domestic monetary policy transmission. On the one hand, it might be that economies with more efficient financial markets display a weaker impact of monetary policy on output as there exist better technologies to alleviate information asymmetries - which are key to credit channel effects. The positive coefficient estimate for $g f_{a l}$ in the regression of Equation (7) could be driven by this relationship as well as the positive correlation between financial market development and gross foreign asset and liability positions in the data. On the other hand, economies with more developed financial markets are typically more leveraged, which could be associated with stronger credit channel effects; more developed financial markets may also invest more in foreign assets denominated in foreign currency due to better risk management abilities. As a consequence, the impact of more advanced financial market development on monetary policy transmission could also show up as a negative coefficient estimate for $n f x_{i}$ in Equation (7). However, none of these hypotheses are borne out by the data. Table 11 shows that including financial market development - as proxied by the logarithm of private credit relative to GDP in Equation (7) does not change our baseline results.

\subsubsection{Financial Sector Size}

Large gross foreign asset and liability positions are typically a feature of economies with large financial sectors (in terms of their contribution to aggregate GDP) which are heavily engaged in cross-border financial intermediation. And monetary policy could be less effective in economies with such financial sectors as international demand for financial intermediation services is not sensitive to domestic interest rates. As a consequence, the positive coefficient estimate for $g \mathrm{fal}_{i}$ could stem from the positive correlation between the size of economies' external balance sheets and their financial sectors, as well as the dampening impact of financial sector size on domestic monetary policy effectiveness. However, Table 11 shows that when we add the financial sector value added share as an explanatory variable the results do not support this hypothesis. ${ }^{29}$

\footnotetext{
${ }^{29}$ The data are taken from the EU KLEMS database.
} 


\subsubsection{Share of Variable-Rate Housing Loans}

Euro area economies exhibit differences in the share of variable-rate housing loans that could play an important role for the asymmetries in domestic monetary policy transmission. For example, while only a small fraction of housing loans in France, Belgium and the Netherlands are subject to variable rates, almost all such loans are subject to variable rates in Finland, Slovenia and Ireland; and, as shown in Figure 2 this aligns with differences in the impact of monetary policy on output across euro area economies. However, the results in Table 11 suggest that our baseline results are unaffected by the inclusion of the share of variable-rate housing loans as still another control in Equation (7).

Figure 11 shows that also the cumulated impact of global financial cycle and net foreign currency exposure effects on domestic monetary policy effectiveness under the robustness checks considered in Section 5.3 are similar to the baseline.

\subsection{Levels vs. Logarithms of the Variables}

Finally, Tables 12 to 14 document that our results are also unchanged if we take the level rather than the logarithm of gross foreign asset and liability positions.

\section{Conclusion}

This paper investigates whether the classic Mundell-Flemming trilemma has morphed into a dilemma due to financial globalisation since the 1990s. We estimate the output response to a domestic monetary policy shock for a sample of advanced and emerging market economies using an MCSGVAR model, and examine whether heterogeneities in domestic monetary policy transmission can be explained by cross-country differences in global financial integration patterns. The results suggest that the impact of financial globalisation on domestic monetary policy effectiveness depends on the relative importance of two salient features of financial globalisation: the size of economies' external balance sheets, which determines the extent to which global financial cycles influence domestic financial conditions and thereby reduce domestic monetary policy effectiveness; and the currency exposure of economies' external balance sheets, which may give rise to exchange rate valuation effects that strengthen domestic monetary policy effectiveness. As the latter can only play out if an economy's exchange rates is flexible, the choice of the exchange rate regime remains critical to monetary policy autonomy under free capital mobility. Hence, our results suggest that the trilemma remains valid.

Our results have implications for policy and academia. From a policy perspective, insofar as valuation effects on economies' external balance sheets arising from exchange rate movements grow 
in importance, central banks might need to re-assess the way their monetary policy transmits to the economy. In particular, while the traditional interest rate channel might lose significance due to the increasing influence of global financial markets on domestic financial conditions, the exchange rate channel may gain importance due to growing net foreign currency exposures of economies' external balance sheets. As a result, the exchange rate channel matters not only because of its importance for import/export prices and quantities but, increasingly so, because of wealth effects. From an academic perspective, our finding that exchange rate valuation effects on economies' external balance sheets have economically important implications for the transmission of domestic shocks suggests that these should become a standard element in openeconomy DSGE models. Specifically, the rotation in the transmission channels of monetary policy may have important implications for the design of optimal monetary policy, and the gains from international monetary policy coordination. Finally, future research should seek to break down external balance sheets by sector to investigate whether there are heterogeneities in the importance of exchange rate valuation effects between the public, household, corporate sector and financial sectors.

\section{References}

Agrippino, S., Rey, H., 2014. World Asset Markets and the Global Financial Cycle. mimeo.

Allen, F., 2004. Financial Systems in Europe, the USA, and Asia. Oxford Review of Economic Policy 20 (4), 490-508.

Auer, S., 2014. Monetary Policy Shocks and Foreign Investment Income: Evidence from a large Bayesian VAR. Swiss National Bank Working Paper 2014-02.

Bekaert, G., Hoerova, M., Lo Duca, M., 2013. Risk, Uncertainty and Monetary Policy. Journal of Monetary Economics 60 (7), 771-788.

Benetrix, A., Lane, P., Shambaugh, J., forthcoming. International Currency Exposures, Valuation Effects and the Global Financial Crisis. Journal of International Economics.

Bernanke, B., 2007. Globalization and Monetary Policy. Speech at the Fourth Economic Summit, Stanford Institute for Economic Policy Research.

Bluedorn, J., Bowdler, C., 2010. The Empirics of International Monetary Transmission: Identification and the Impossible Trinity. Journal of Money, Credit and Banking 42 (4), 679-713.

Botero, J., Djankov, S., Porta, R., Lopez-De-Silanes, F. C., 2004. The Regulation of Labor. The Quarterly Journal of Economics 119 (4), 1339-1382.

Bruno, V., Shin, H., 2014. Capital Flows and the Risk-Taking Channel of Monetary Policy. mimeo, Princeton University. 
Burger, J., Sengupta, R., Warnock, F., Warnock, V., 2014. US Investment in Global Bonds: As the Fed Pushes, Some EMEs Pull. NBER Working Paper (20571).

Burger, J., Warnock, F., Warnock, V., 2010. Emerging Local Currency Bond Markets. NBER Working Paper (16249).

Carlino, G., DeFina, R., 1998. The Differential Regional Effects of Monetary Policy. Review of Economics and Statistics 80 (4), 527-587.

Cetorelli, N., Goldberg, L. S., 2012. Banking Globalization and Monetary Transmission. Journal of Finance 67 (5), 1811-1843.

Chinn, M., Ito, H., 2003. A New Measure of Capital Account Openness. Journal of Comparative Policy Analysis 10 (3), 309-322.

Christoffel, K., Coenen, G., Warne, A., 2008. The New Area-Wide Model of the Euro Area: A Micro-Founded Open-Economy Model for Forecasting and Policy Analysis. ECB Working Paper 0944.

Chudik, A., Pesaran, M., 2013. Econometric Analysis of High Dimensional VARs Featuring a Dominant Unit. Econometric Reviews 32 (5-6), 592-649.

Claessens, S., Horen, N., 2014. Foreign Banks: Trends and Impact. Journal of Money, Credit and Banking 46 (s1), 295-326.

Cwik, T., Müller, G. J., Wolters, M. H., 2011. Does Trade Integration Alter Monetary Policy Transmission? Journal of Economic Dynamics and Control 35 (4), 545-564.

Dedola, L., Lippi, F., 2005. The Monetary Transmission Mechanism: Evidence from the Industries of Five OECD Countries. European Economic Review 49 (6), 1543-1569.

Devereux, M., Senay, O., Sutherland, A., 2013. Nominal Stability and Financial Globalization. Discussion Paper Series, Department of Economics 201311, Department of Economics, University of St. Andrews.

Devereux, M., Sutherland, A., 2010. Valuation Effects and the Dynamics of Net External Assets. Journal of International Economics 80 (1), 129-143.

Devereux, M., Yetman, J., 2014. Globalisation, Pass-through and the Optimal Policy Response to Exchange Rates. Journal of International Money and Finance 49 (PA), 104-128.

Devereux, M. B., Sutherland, A., 2008. Financial Globalization and Monetary Policy. Journal of Monetary Economics 55 (8), 1363-1375.

Draghi, M., 2014. Monetary Policy Communication in Turbulent Times. Speech at the Conference De Nederlandsche Bank 200 years: Central banking in the next two decades, Amsterdam, 24 April 2014. 
Engel, C., 2014. Exchange Rate Stabilization and Welfare. Annual Review of Economics 6 (1), $155-177$.

Engel, C., Matsumoto, A., 2009. The International Diversification Puzzle When Goods Prices Are Sticky: It's Really about Exchange-Rate Hedging, Not Equity Portfolios. American Economic Journal: Macroeconomics 1 (2), 155-88.

Farhi, E., Werning, I., 2013. Dilemma not Trilemma? Capital Controls and Exchange Rates with Volatile Capital Flows. Working Paper 133566, Harvard University.

Forbes, K., Warnock, F., 2012. Capital Flow Waves: Surges, Stops, Flight, and Retrenchment. Journal of International Economics 88 (2), 235-251.

Frankel, J., Schmukler, S., Serven, L., 2004. Global Transmission of Interest Rates: Monetary Independence and Currency Regime. Journal of International Money and Finance 23 (5), 701-733.

Georgiadis, G., forthcoming. Examining Asymmetries in the Transmission of Monetary Policy in the Euro Area: Evidence from a Mixed Cross-Section Global VAR Model. European Economic Review.

Ghosh, A., Qureshi, M., Kim, J., Zalduendo, J., 2014. Surges. Journal of International Economics $92(2), 266-285$.

Goldberg, L., 2013. Banking Globalization, Transmission, and Monetary Policy Autonomy. NBER Working Papers 19497, National Bureau of Economic Research, Inc.

Hale, G., Jones, P., Spiegel, M., 2014. The Rise in Home Currency Issuance. Federal Reserve Bank of San Francisco Working Paper 2014-19.

Hausmann, R., Panizza, U., 2011. Redemption or Abstinence? Original Sin, Currency Mismatches and Counter Cyclical Policies in the New Millennium. Journal of Globalization and Development 2 (1), 1-35.

He, D., McCauley, R., 2013. Transmitting Global Liquidity to East Asia: Policy Rates, Bond Yields, Currencies and Dollar Credit. BIS Working Paper 431, Bank for International Settlements.

Hellerstein, R., 2011. Global Bond Risk Premiums. Staff Reports 499, Federal Reserve Bank of New York.

Ilzetzki, E., Reinhart, C., Rogoff, K., 2010. Exchange Rate Arrangements Entering the 21st Century: Which Anchor Will Hold? mimeo, London School of Economics.

Ito, H., 2014. Monetary Policy in Asia and the Pacific in the Post, Post-Crisis Era. mimeo. 
Jarocinski, M., 2010. Responses to Monetary Policy Shocks in the East and the West of Europe: A Comparison. Journal of Applied Econometrics 25 (5), 833-868.

Kamin, S., 2010. Financial Globalization and Monetary Policy. Tech. Rep. 1002, Board of Governors of the Federal Reserve System.

Klein, M., Shambaugh, J., 2013. Rounding the Corners of the Policy Trilemma: Sources of Monetary Policy Autonomy. NBER Working Papers 19461, National Bureau of Economic Research, Inc.

Lane, P., Milesi-Ferretti, G.-M., 2001. The External Wealth of Nations: Measures of Foreign Assets and Liabilities for Industrial and Developing Countries. Journal of International Economics 55 (2), 263-294.

Lane, P., Milesi-Ferretti, G. M., 2008. International Investment Patterns. The Review of Economics and Statistics 90 (3), 538-549.

Lane, P., Shambaugh, J., 2010. Financial Exchange Rates and International Currency Exposures. American Economic Review 100 (1), 518-40.

Lane, P. R., Milesi-Ferretti, G. M., 2007. The External Wealth of Nations Mark II: Revised and Extended Estimates of Foreign Assets and Liabilities, 1970-2004. Journal of International Economics 73 (2), 223-250.

Lo Duca, M., Nicoletti, G., Vidal Martinez, A., 2014. Global Corporate Bond Issuance: What Role for US Quantitative Easing? ECB Working Paper (1649).

McCauley, R., McGuire, P., Sushko, V., 2014. US Monetary Policy, Leverage, and Offshore Dollar Credit. mimeo.

Meier, S., 2013. Financial Globalization and Monetary Transmission. Federal Reserve Bank of Dallas Globalization and Monetary Policy Institute Working Paper 145.

Miniane, J., Rogers, J., 2007. Capital Controls and the International Transmission of U.S. Money Shocks. Journal of Money, Credit and Banking 39 (5), 1003-1035.

Obstfeld, M., 2014. Trilemmas and Tradeoffs: Living with Financial Globalization. mimeo.

Obstfeld, M., Shambaugh, J., Taylor, A., 2005. The Trilemma in History: Tradeoffs Among Exchange Rates, Monetary Policies, and Capital Mobility. The Review of Economics and Statistics 87 (3), 423-438.

Pesaran, M., Schuermann, T., Weiner, S. M., 2004. Modeling Regional Interdependencies Using a Global Error-Correcting Macroeconometric Model. Journal of Business and Economic Statistics 22 (2), 129-162. 
Philippon, T., Zettelmeyer, J., Borensztein, E., 2001. Monetary Independence in Emerging Markets: Does the Exchange Rate Regime Make a Difference? IMF Working Papers 01/1.

Quinn, D., Voth, H.-J., 2008. A Century of Global Equity Market Correlations. American Economic Review 98 (2), 535-40.

Reinhart, C., Reinhart, V., 2009. Capital Flow Bonanzas: An Encompassing View of the Past and Present. In: NBER International Seminar on Macroeconomics 2008. NBER Chapters. National Bureau of Economic Research, pp. 9-62.

Rey, H., 2013. Dilemma not Trilemma: The Global Cycle and Monetary Policy Independence. Proceedings - Economic Policy Symposium - Jackson Hole, 1-2.

Shambaugh, J., 2004. The Effect of Fixed Exchange Rates on Monetary Policy. The Quarterly Journal of Economics 119 (1), 300-351.

Shin, H. S., 2012. Global Banking Glut and Loan Risk Premium. IMF Economic Review 60 (2), 155-192.

Smets, F., Wouters, R., 2003. An Estimated Dynamic Stochastic General Equilibrium Model of the Euro Area. Journal of the European Economic Association 1 (5), 1123-1175.

Tille, C., 2008. Financial Integration and the Wealth Effect of Exchange Rate Fluctuations. Journal of International Economics 75 (2), 283-294.

Weber, A., 2008. Globalisation, Monetary Policy and the Euro. Speech at the Norges Bank Conference on Monetary Policy - Jarle Bergo Colloquium - "Globalisation and Monetary Policy".

Woodford, M., 2007. Globalization and Monetary Control. In: International Dimensions of Monetary Policy. NBER Chapters. National Bureau of Economic Research, Inc, pp. 13-77.

Yellen, J., 2006. Monetary Policy in a Global Environment. Speech at The Euro and the Dollar in a Globalized Economy Conference. 


\section{A Global Solution of the MCSGVAR Model}

Denoting by $\boldsymbol{z}_{i t}=\left(\boldsymbol{x}_{i t}^{\prime}, \boldsymbol{x}_{i t}^{* \prime}\right)^{\prime}, \boldsymbol{A}_{i 0}=\left(\boldsymbol{I}_{k_{i}},-\boldsymbol{\Gamma}_{i 0}\right), \boldsymbol{A}_{i j}=\left(\boldsymbol{\Phi}_{i j}, \boldsymbol{\Gamma}_{i j}\right)$, and $q_{i}=\max \left(p_{i}, p_{i}^{*}\right)$, Equation (2) can be written as

$$
\boldsymbol{A}_{i 0} \cdot \boldsymbol{z}_{i t}=\boldsymbol{a}_{i}+\sum_{j=1}^{q_{i}} \boldsymbol{A}_{i j} \cdot \boldsymbol{z}_{i, t-j}+\boldsymbol{u}_{i t}
$$

The vector of endogenous and "foreign" variables of unit $i$ can be linked to the vector which stacks the endogenous variables of all units by $\boldsymbol{z}_{i t}=\boldsymbol{W}_{i} \boldsymbol{x}_{t}$, where $\boldsymbol{W}_{i}$ is a link matrix containing that aggregates all other units' endogenous variables into unit $i$ 's "foreign" variable $\boldsymbol{x}_{i t}^{*}$. Equation (A.1) can then be written as

$$
\boldsymbol{A}_{i 0} \cdot \boldsymbol{W}_{i} \cdot \boldsymbol{x}_{t}=\boldsymbol{a}_{i}+\sum_{j=1}^{q_{i}} \boldsymbol{A}_{i j} \cdot \boldsymbol{W}_{i} \cdot \boldsymbol{x}_{t-j}+\boldsymbol{u}_{i t}
$$

With $q=\max \left(q_{1}, q_{2}, \ldots, q_{N}\right)$, the unit-specific models in Equation (A.2) can now be stacked to deliver the GVAR model

$$
\boldsymbol{G}_{0} \cdot \boldsymbol{x}_{t}=\boldsymbol{a}+\sum_{j=1}^{q} \boldsymbol{G}_{j} \cdot \boldsymbol{x}_{t-j}+\boldsymbol{u}_{t}
$$

where

$$
\boldsymbol{G}_{0}=\left[\begin{array}{c}
\boldsymbol{A}_{10} \boldsymbol{W}_{1} \\
\boldsymbol{A}_{20} \boldsymbol{W}_{2} \\
\vdots \\
\boldsymbol{A}_{N 0} \boldsymbol{W}_{N}
\end{array}\right], \quad \boldsymbol{a}=\left[\begin{array}{c}
\boldsymbol{a}_{1} \\
\boldsymbol{a}_{2} \\
\vdots \\
\boldsymbol{a}_{N}
\end{array}\right], \quad \boldsymbol{G}_{j}=\left[\begin{array}{c}
\boldsymbol{A}_{1 j} \boldsymbol{W}_{1} \\
\boldsymbol{A}_{2 j} \boldsymbol{W}_{2} \\
\vdots \\
\boldsymbol{A}_{N j} \boldsymbol{W}_{N}
\end{array}\right], \quad \boldsymbol{u}_{t}=\left[\begin{array}{c}
\boldsymbol{u}_{1 t} \\
\boldsymbol{u}_{2 t} \\
\vdots \\
\boldsymbol{u}_{N t}
\end{array}\right]
$$

The global solution of the model is then given by

$$
\boldsymbol{x}_{t}=\boldsymbol{b}+\sum_{j=1}^{q} \boldsymbol{F}_{j} \cdot \boldsymbol{x}_{t-j}+\boldsymbol{\epsilon}_{t},
$$

where $\boldsymbol{b}=\boldsymbol{G}_{0}^{-1} \boldsymbol{a}, \boldsymbol{F}_{j}=\boldsymbol{G}_{0}^{-1} \boldsymbol{G}_{j}$, and $\boldsymbol{\epsilon}_{t}=\boldsymbol{G}_{0}^{-1} \boldsymbol{u}_{t}$. Estimation of the MCSGVAR model amounts to (i) estimating each unit's VARX model in Equation (2) by ordinary least squares, (ii) using the link matrices $\boldsymbol{W}_{i}$ in stacking the relevant estimated matrices as in Equation (A.4), and (iii) obtaining the global solution in Equation (A.5). 


\section{B Interpretation of Net Foreign Currency Exposure}

Consider an economy's net foreign asset and liability position relative to GDP denoting by $Y_{i t}$ GDP, and by $A_{i t}$ and $L_{i t}$ the level of foreign assets and liabilities

$$
n f a l_{i t}=\frac{A_{i t}-L_{i t}}{Y_{i t}}=\frac{w_{i t}^{A} A_{i t}+\left(1-w_{i t}^{A}\right) A_{i t}-w_{i t}^{L} L_{i t}-\left(1-w_{i t}^{L}\right) L_{i t}}{Y_{i t}} .
$$

After a uniform percentage change in the economy's exchange rate vis-à-vis all foreign currencies by $g^{f x}$ the value of the net foreign asset and liability position relative to GDP is given by

$$
n f a l_{i t}^{\prime}=\frac{\left(1+g^{f x}\right) w_{i t}^{A} A_{i t}+\left(1-w_{i t}^{A}\right) A_{i t}-\left(1+g^{f x}\right) w_{i t}^{L} L_{i t}-\left(1-w_{i t}^{L}\right) L_{i t}}{Y_{i t}},
$$

and the difference relative to the initial net foreign asset and liability position relative to GDP is given by

$$
\begin{aligned}
\Delta n f a_{i t} & =n f a l_{i t}^{\prime}-n f a l_{i t}=\frac{g^{f x}\left(w_{i t}^{A} A_{i t}-w_{i t}^{L} L_{i t}\right)}{Y_{i t}} \\
& =g^{f x} \cdot \frac{\left(w_{i t}^{A} A_{i t}-w_{i t}^{L} L_{i t}\right)}{Y_{i t}} \frac{A_{i t}+L_{i t}}{A_{i t}+L_{i t}}=g^{f x} \cdot\left(w_{i t}^{A} s_{i t}^{A}-w_{i t}^{L} s_{i t}^{L}\right) g f a l_{i t} \\
& =g^{f x} \cdot n f x_{i t} .
\end{aligned}
$$

\section{Construction of Indicators for Industry Mix and Labor Mar- ket Rigidities}

The metric for industry mix is calculated as the sum of standardised data for the share of aggregate output accounted for by (durables) manufacturing, construction and services; the sign for services is reversed, as a higher share of services typically suggests that demand is less interest rate-sensitive. We take the data from the OECD STAN Database and the World Bank's World Development Indicators.

The labour market rigidities metric is composed of two sub-metrics: real wage and unemployment rigidities. For real wage rigidities, we consider union density taken from the OECD as well as the Social Security Index from Botero et al. (2004) which summarises information on old age, disability, death, sickness, health and unemployment benefits. For unemployment rigidities, we also consider two measures. First, we consider the OECD's Strictness of Employment Protection Index, which is based on 21 items covering three aspects of employment protection: individual dismissal of workers with regular contracts, additional provisions for collective dismissals and the regulation of temporary contracts. Second, we consider the Regulation of Labour Index from Botero et al. (2004) which summarises information on alternative employment contracts, the 
cost of increasing hours worked and firing workers, dismissal procedures, labour union power and collective disputes. The individual labour market rigidities series are standardised and summed, with a negative sign for the variables for unemployment rigidities, as they dampen the response of output to a shock. The construction of the industry structure and labour market rigidities indicators is the same as in Georgiadis (forthcoming).

\section{Imputation of Missing Data for the Explanatory Variables in Equation (7) in the Expanded Country Sample}

We use the share of manufacturing (Regulation of Labour Index and Social Security Index) to impute missing data for the durable goods manufacturing share (union density) for Brazil, Chile, Indonesia, Thailand and South Africa; the Social Security Index to impute missing data for the Strictness of Employment Protection Indicator for Thailand. For the share of construction for Brazil, Chile, Indonesia, Thailand and South Africa we resort to data from the World-InputOutput Database and national sources. 


\section{E Tables}

Table 1: Gross Foreign Asset and Liability Positions and Net Foreign Currency Exposures

\begin{tabular}{|c|c|c|c|c|}
\hline & \multicolumn{2}{|c|}{ Change 1999-2009 } & \multicolumn{2}{|c|}{2009 level } \\
\hline & GFA/GDP (log) & Net FX exp. & GFA/GDP (log) & Net FX exp. \\
\hline $\mathrm{AUT}$ & 0.72 & 0.58 & 1.91 & 0.25 \\
\hline BEL & 0.54 & 0.59 & 2.39 & 0.60 \\
\hline $\mathrm{DEU}$ & 0.45 & 0.16 & 1.64 & 0.22 \\
\hline ESP & 0.47 & 0.11 & 1.49 & 0.16 \\
\hline FIN & 0.25 & 0.25 & 1.71 & 0.20 \\
\hline FRA & 0.43 & 0.01 & 1.78 & 0.20 \\
\hline GRC & 0.64 & 0.27 & 1.43 & 0.25 \\
\hline IRL & 0.92 & 1.54 & 3.43 & 2.69 \\
\hline ITA & 0.18 & 0.22 & 1.25 & 0.09 \\
\hline NLD & 0.42 & 0.49 & 2.22 & 0.95 \\
\hline PRT & 0.61 & 0.21 & 1.77 & 0.18 \\
\hline SVN & 0.63 & 0.36 & 1.21 & 0.40 \\
\hline EA & 0.42 & 0.21 & 1.68 & 0.28 \\
\hline AEs & 0.31 & 0.39 & 1.44 & 0.93 \\
\hline EMEs & 0.10 & 0.29 & 0.82 & 0.19 \\
\hline
\end{tabular}

Note: The table reports the changes in economies' gross foreign asset and liability positions relative to GDP as well as net foreign currency expsoures during 1999-2009; the table also reports their levels in 2009. For the gross foreign asset and liability position we report the logarithm of one plus the original value.

Table 2: Country Groups

\begin{tabular}{l|l}
\hline \hline Region & Countries \\
\hline Indiv. countries/units & ALB, AUS, AUT, BAL, BEL, BGR, BOL, BRA, CAN, CHE, CHL, CHN, \\
& COL, CRI, CZE, DEU, DNK, ECB, EGY, ESP, FIN, FRA, GBR, GRC, \\
& HKG, HRV, HUN, IDN, IND, IRL, ISR, ITA, JOR, JPN, KOR, LUX, \\
& MAR, MEX, MYS, NLD, NOR, NZL, OIL, OPC, PER, PHL, POL, PRT, \\
& PRY, ROU, RUS, SGP, SVK, SVN, SWE, THA, TUR, USA, ZAF \\
Baltics (BAL) & EST, LVA, LTU \\
Oil exporting countries & VEN, ECU, SAU \\
& \\
\hline
\end{tabular}

Note: The table reports the countries included and details the composition of the country groups. 
Table 3: Data Sources

\begin{tabular}{|c|c|c|c|c|}
\hline Unit & Real GDP & Prices & Short-term interest rates & Oil prices \\
\hline ALB & A914GDPC@IMFWEO & H914PC@EMERGE & C914IC@IFS & \\
\hline AUS & S193NGCD@G10 & H193PC@G10 & N193RI3@G10 & \\
\hline AUT & J122GDPT@EUDATA & $\mathrm{H} 122 \mathrm{PC} @ \mathrm{G} 10$ & & \\
\hline BEL & S124NGCD@G10 & H124PC@G10 & & \\
\hline BGR & J918GDPT@EUDATA & H918PC@EMERGE & C918IM@IFS & \\
\hline $\mathrm{BOL}$ & H218NGCD@EMERGE & H218PC@EMERGE & C218IM@IFS & \\
\hline BRA & H223NGCD@EMERGE & H223PC@EMERGE & C223IM@IFS & \\
\hline CAN & S156NGCD@G10 & H156PC@G10 & C156IM@IFS & \\
\hline $\mathrm{CHE}$ & S146NGCD@G10 & H146PC@G10 & N146RI3@G10 & \\
\hline CHL & H228NGCD@EMERGE & H228PC@EMERGE & N228RTAR@EMERGE & \\
\hline $\mathrm{CHN}$ & H924NGCD@EMERGE & H924PC@EMERGE & N924RTAR@EMERGE & \\
\hline $\mathrm{COL}$ & S233NGPC@EMERGELA & H233PC@EMERGE & C233IM@IFS & \\
\hline CRI & H238NGCD@EMERGE & H238PC@EMERGE & C238IC@IFS & \\
\hline CZE & J935GDPT@EUDATA & H935PC@EMERGE & N935RI3@EMERGE & \\
\hline DEU & S134NGCD@G10 & C134PC@IFS & & \\
\hline DNK & S128NGCD@G10 & H128PC@G10 & N128RTAR@G10 & \\
\hline $\mathrm{ECB}$ & & & C023IM@IFS & \\
\hline $\mathrm{ECU}$ & C248GDPI@IFS & H248PC@EMERGE & C248IC@IFS & \\
\hline EGY & A469GDPC@IMFWEO & H469PC@EMERGE & N469RTAR@EMERGE & \\
\hline ESP & S184NGCD@G10 & H184PC@G10 & & \\
\hline EST & J939GDPT@EUDATA & H939PC@EMERGE & C939IM@IFS & \\
\hline FIN & S172NGCD@G10 & H172PC@G10 & & \\
\hline FRA & S132NGCD@G10 & $\mathrm{H} 132 \mathrm{PC} @ \mathrm{G} 10$ & & \\
\hline GBR & S112NGCD@G10 & H112PC@G10 & N112RI3@G10 & \\
\hline GRC & C174GDPI@IFS & H174PC@G10 & C174IC@IFS & \\
\hline HKG & H532NGCD@EMERGE & H532PC@EMERGE & N532RI3@EMERGE & \\
\hline HRV & C960GDPI@IFS & H960PC@EMERGE & C960IM@IFS & \\
\hline HUN & H944NGCD@EMERGE & H944PC@EMERGE & N944RTAR@EMERGE & \\
\hline IDN & H536NGCD@EMERGE & H536PC@EMERGE & C536IM@IFS & \\
\hline IND & H534NGCD@EMERGE & C534PC@IFS & C534IC@IFS & \\
\hline IRL & S178NGCD@G10 & H178PC@G10 & & \\
\hline ISR & S436NGPC@EMERGEMA & H436PC@EMERGE & N436RI3@EMERGE & \\
\hline ITA & S136NGCD@G10 & H136PC@G10 & & \\
\hline JOR & H439NGCD@EMERGE & H439PC@EMERGE & C439IC@IFS & \\
\hline JPN & S158NGCD@G10 & H158PC@G10 & C158IM@IFS & \\
\hline KOR & S542NGPC@EMERGEPR & H542PC@EMERGE & C542IM@IFS & \\
\hline LTU & H946NGCD@EMERGE & H946PC@EMERGE & C946IM@IFS & \\
\hline LUX & S137NGCD@G10 & H137PC@G10 & & \\
\hline LVN & H941NGCD@EMERGE & H941PC@EMERGE & C941IM@IFS & \\
\hline MAR & C686GDPI@IFS & C686PC@IFS & C686IM@IFS & \\
\hline MEX & S273NGPC@EMERGE & H273PC@EMERGE & C273IM@IFS & \\
\hline MYS & H548NGCD@EMERGE & H548PC@EMERGE & C548IM@IFS & \\
\hline NLD & S138NGCD@G10 & H138PC@G10 & & \\
\hline NOR & S142NGCD@G10 & H142PC@G10 & N142RI3@G10 & \\
\hline NZL & S196NGCD@G10 & H196PC@G10 & C196IM@IFS & \\
\hline PER & H293NGCD@EMERGE & H293PC@EMERGE & C293IM@IFS & \\
\hline PHL & H566NGCD@EMERGE & C566PC@IFS & C566IM@IFS & \\
\hline POL & H964NGCD@EMERGE & H964PC@EMERGE & C964IM@IFS & \\
\hline PRT & S182NGCD@G10 & H182PC@G10 & & \\
\hline PRY & H288NGCD@EMERGE & H288PC@EMERGE & C288IM@IFS & \\
\hline OIL & & & & N112POIL@G10 \\
\hline ROU & A968GDPC@IMFWEO & H968PC@EMERGE & C968IM@IFS & \\
\hline RUS & H922NGCD@EMERGE & H922PC@EMERGE & C922IM@IFS & \\
\hline SAU & A456GDPC@IMFWEO & H456PC@EMERGE & N456RD3M@EMERGEMA & \\
\hline SGP & H576NGCD@EMERGE & S576PC@EMERGEPR & N576RI3@EMERGE & \\
\hline SVK & H936NGCD@EMERGE & H936PC@EMERGE & C936IC@IFS & \\
\hline SVN & H961NGCD@EMERGE & H961PC@EMERGE & C961IM@IFS & \\
\hline SWE & S144NGCD@G10 & H144PC@G10 & N144RI3@G10 & \\
\hline THA & S578NGPC@EMERGEPR & H578PC@EMERGE & C578IM@IFS & \\
\hline TUR & H186NGCD@EMERGE & H186PC@EMERGE & C186IM@IFS & \\
\hline USA & S111NGCD@G10 & C111PC@IFS & N111RI3@G10 & \\
\hline VEN & S299GPC@EMERGELA & H299PC@EMERGE & C299IM@IFS & \\
\hline ZAF & S199NGPC@EMERGEMA & H199PC@EMERGE & C199IM@IFS & \\
\hline
\end{tabular}

Note: The table provides the Haver series codes of the variables used. Data available only at annual frequency are interpolated to quarterly frequency.

Table 4: Descriptive Statistics

\begin{tabular}{lcccc}
\hline \hline & mean & min & $\max$ & sd \\
\hline Trough response of GDP & -0.23 & -0.36 & -0.15 & 0.08 \\
Industry mix & -0.35 & -3.94 & 3.73 & 2.87 \\
Labor market rigidities & -0.03 & -4.49 & 4.24 & 2.65 \\
Net FX exposure & 0.28 & -0.12 & 1.51 & 0.43 \\
GFA/GDP $(\log )$ & 1.64 & 0.94 & 3.01 & 0.57 \\
\hline \hline
\end{tabular}


Table 5: Determinants of Monetary Transmission in the Euro Area

\begin{tabular}{lllll}
\hline \hline & \multicolumn{1}{c}{$(1)$} & $(2)$ & $(3)$ & \multicolumn{1}{c}{$(4)$} \\
\hline Labor market rigidities & $-0.01^{+}$ & -0.01 & -0.01 & $-0.01^{* *}$ \\
& $(0.17)$ & $(0.22)$ & $(0.27)$ & $(0.03)$ \\
& & & & \\
Industry mix & $-0.01^{*}$ & $-0.01^{+}$ & $-0.01^{+}$ & $-0.01^{+}$ \\
& $(0.09)$ & $(0.11)$ & $(0.16)$ & $(0.13)$ \\
Net FX exposure & & & & \\
& & & $-0.05^{+}$ & $-0.21^{* * *}$ \\
GFA/GDP (log) & & & $(0.12)$ & $(0.00)$ \\
& & -0.00 & & $0.14^{* * *}$ \\
\hline Adj. R-squared & 0.47 & 0.40 & & $(0.00)$ \\
Observations & 12 & 12 & 12 & 0.83 \\
\hline
\end{tabular}

$p$-values in parentheses

Robust standard errors.

${ }^{+} p<0.2,{ }^{*} p<0.1,{ }^{* *} p<0.05,{ }^{* * *} p<0.01$

Table 6: Descriptive Statistics for Non-Euro Area AEs

\begin{tabular}{lcccc}
\hline \hline & mean & $\min$ & $\max$ & $\mathrm{sd}$ \\
\hline Trough response of GDP & -0.10 & -0.18 & -0.05 & 0.05 \\
Industry mix & -1.96 & -2.87 & 0.19 & 1.16 \\
Labor market rigidities & 2.73 & 1.01 & 4.43 & 1.20 \\
Net FX exposure & 0.55 & -0.18 & 1.02 & 0.40 \\
GFA/GDP (log) & 1.38 & 0.89 & 2.12 & 0.38 \\
\hline \hline
\end{tabular}

Table 7: Descriptive Statistics for Non-Euro Area EMEs

\begin{tabular}{lcccc}
\hline \hline & mean & $\min$ & $\max$ & $\mathrm{sd}$ \\
\hline Trough response of GDP & -0.11 & -0.20 & -0.02 & 0.06 \\
Industry mix & 1.67 & -2.54 & 6.44 & 2.91 \\
Labor market rigidities & -1.45 & -7.32 & 0.58 & 2.00 \\
Net FX exposure & 0.10 & -0.33 & 0.44 & 0.28 \\
GFA/GDP $(\log )$ & 0.87 & 0.61 & 1.27 & 0.20 \\
\hline \hline
\end{tabular}




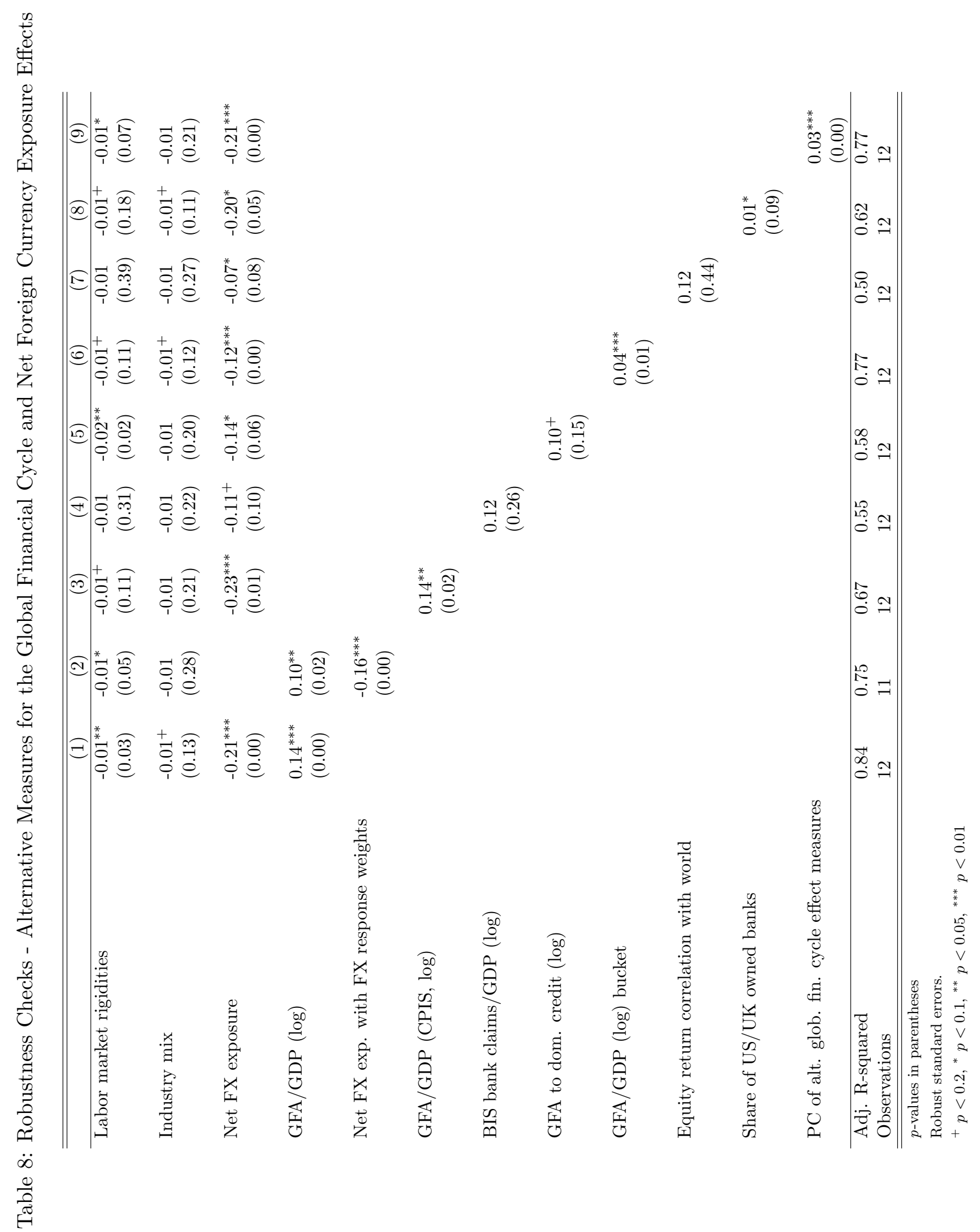




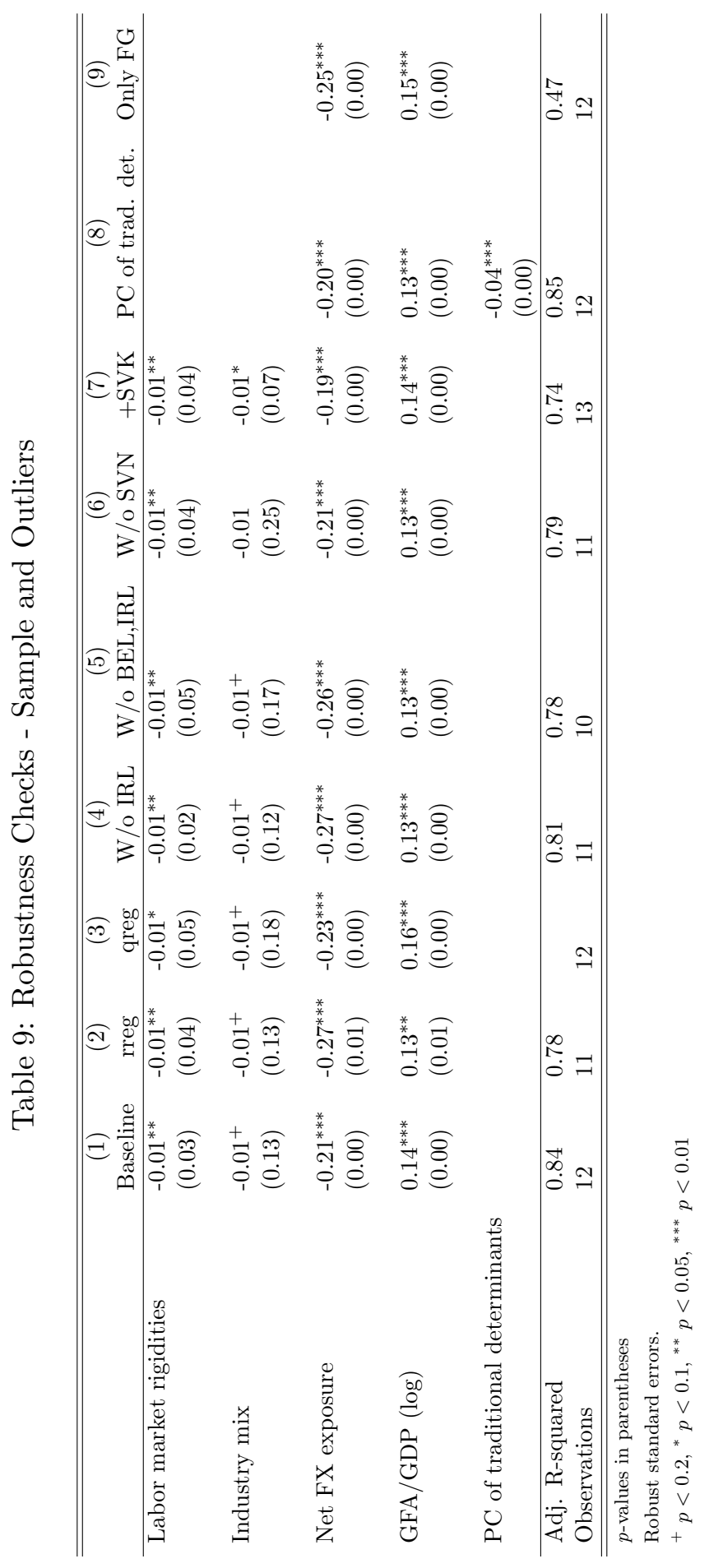


Table 10: Extended Country Sample

\begin{tabular}{|c|c|c|c|c|}
\hline & (1) & $(2)$ & $(3)$ & $(4)$ \\
\hline Labor market rigidities & $\begin{array}{l}-0.01 \\
(0.35)\end{array}$ & $\begin{array}{l}-0.01^{* * *} \\
(0.00)\end{array}$ & $\begin{array}{l}-0.01 \\
(0.31)\end{array}$ & $\begin{array}{l}-0.01^{* * *} \\
(0.00)\end{array}$ \\
\hline Industry mix & $\begin{array}{l}-0.01^{*} \\
(0.06)\end{array}$ & $\begin{array}{l}-0.01^{* *} \\
(0.04)\end{array}$ & $\begin{array}{l}-0.01 \\
(0.23)\end{array}$ & $\begin{array}{l}-0.01^{* *} \\
(0.05)\end{array}$ \\
\hline Net FX exposure & $\begin{array}{l}0.04 \\
(0.33)\end{array}$ & $\begin{array}{l}-0.12^{* * *} \\
(0.00)\end{array}$ & $\begin{array}{l}-0.08 \\
(0.23)\end{array}$ & $\begin{array}{l}-0.10^{* *} \\
(0.02)\end{array}$ \\
\hline GFA/GDP (log) & $\begin{array}{l}-0.10^{* * *} \\
(0.00)\end{array}$ & $\begin{array}{l}0.06^{* *} \\
(0.04)\end{array}$ & & \\
\hline GFA/GDP (CPIS, log) & & & $\begin{array}{l}0.04 \\
(0.49)\end{array}$ & $\begin{array}{l}0.03 \\
(0.37)\end{array}$ \\
\hline EA country dummy & & $\begin{array}{l}-0.17^{* * *} \\
(0.00)\end{array}$ & & $\begin{array}{l}-0.13^{* * *} \\
(0.00)\end{array}$ \\
\hline EA contiguity dummy & & $\begin{array}{l}0.12^{* * *} \\
(0.00)\end{array}$ & & $\begin{array}{l}0.11^{* * *} \\
(0.00)\end{array}$ \\
\hline Domestic credit/GDP (log) & & $\begin{array}{l}0.12^{* * *} \\
(0.00)\end{array}$ & & $\begin{array}{l}0.13^{* * *} \\
(0.01)\end{array}$ \\
\hline Trade/GDP (log) & & $\begin{array}{c}-0.11^{+} \\
(0.12)\end{array}$ & & $\begin{array}{l}-0.07 \\
(0.41)\end{array}$ \\
\hline Observations & 29 & 29 & 29 & 29 \\
\hline Adjusted $R^{2}$ & 0.25 & 0.83 & 0.01 & 0.80 \\
\hline
\end{tabular}




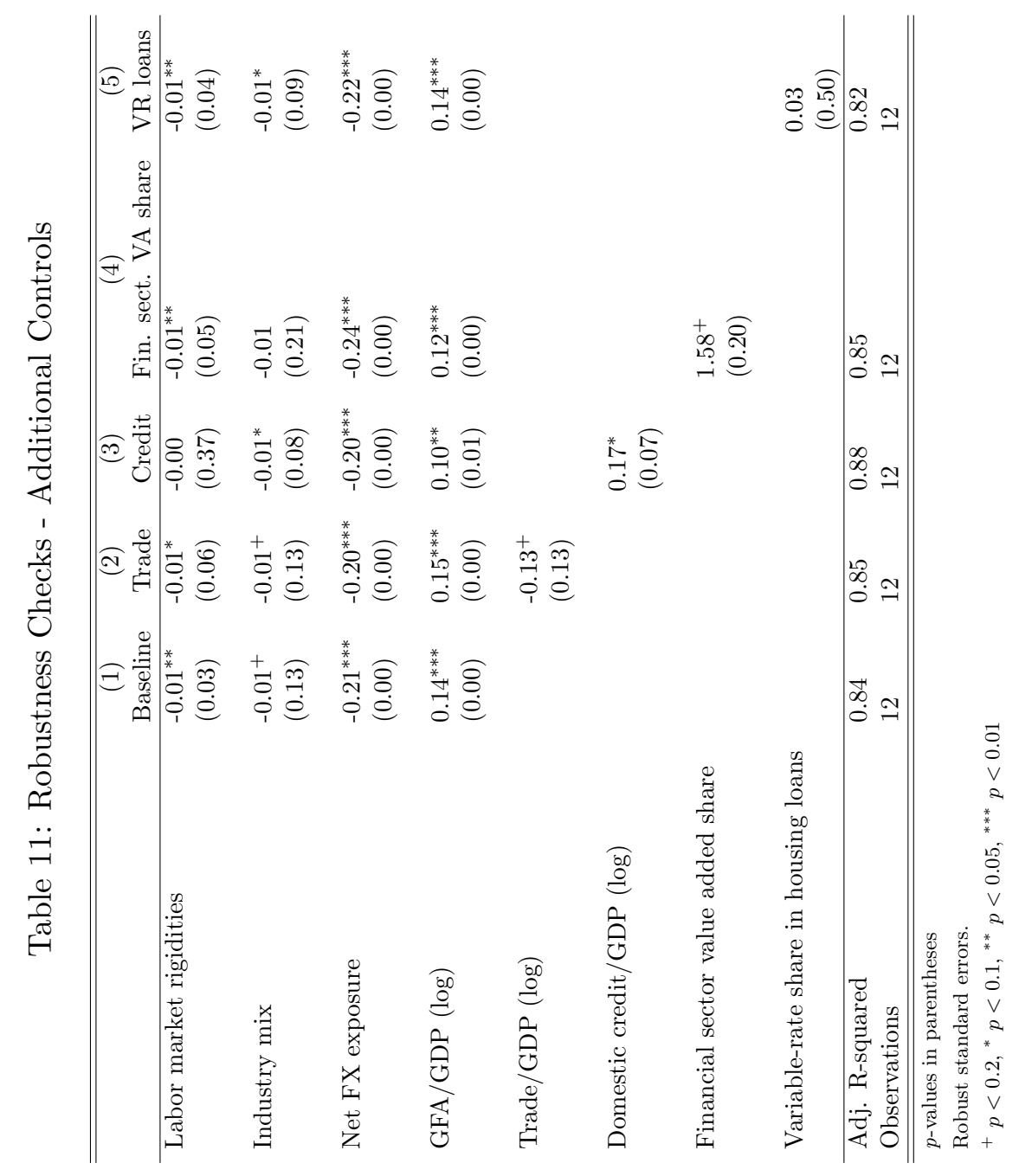


Table 12: Robustness Checks Using the Level of GFA/GDP as Dependent Variable - Alternative Measures for the Global Financial Cycle and Net Foreign Currency Exposure Effects

\begin{tabular}{|c|c|c|c|c|}
\hline & (1) & (2) & (3) & (4) \\
\hline Labor market rigidities & $\begin{array}{l}-0.02^{* * *} \\
(0.01)\end{array}$ & $\begin{array}{l}-0.01^{* *} \\
(0.04)\end{array}$ & $\begin{array}{c}-0.01^{*} \\
(0.09)\end{array}$ & $\begin{array}{l}-0.01 \\
(0.31)\end{array}$ \\
\hline Industry mix & $\begin{array}{c}-0.01^{*} \\
(0.08)\end{array}$ & $\begin{array}{l}-0.01 \\
(0.26)\end{array}$ & $\begin{array}{c}-0.01^{+} \\
(0.13)\end{array}$ & $\begin{array}{l}-0.01 \\
(0.25)\end{array}$ \\
\hline Net FX exposure & $\begin{array}{l}-0.31^{* * *} \\
(0.00)\end{array}$ & & $\begin{array}{l}-0.31^{* * *} \\
(0.00)\end{array}$ & $\begin{array}{l}-0.12^{+} \\
(0.11)\end{array}$ \\
\hline GFA/GDP & $\begin{array}{l}0.02^{* * *} \\
(0.00)\end{array}$ & $\begin{array}{l}0.01^{* *} \\
(0.02)\end{array}$ & & \\
\hline Net FX exp. with FX response weights & & $\begin{array}{l}-0.19^{* * *} \\
(0.00)\end{array}$ & & \\
\hline GFA/GDP (CPIS) & & & $\begin{array}{l}0.04^{* * *} \\
(0.01)\end{array}$ & \\
\hline Non-EA banking assets and liab./GDP (BIS) & & & & $\begin{array}{l}0.07 \\
(0.27)\end{array}$ \\
\hline Adj. R-squared & 0.86 & 0.74 & 0.67 & 0.55 \\
\hline Observations & 12 & 11 & 12 & 12 \\
\hline
\end{tabular}

$p$-values in parentheses

Robust standard errors.

${ }^{+} p<0.2,{ }^{*} p<0.1,{ }^{* *} p<0.05,{ }^{* * *} p<0.01$ 


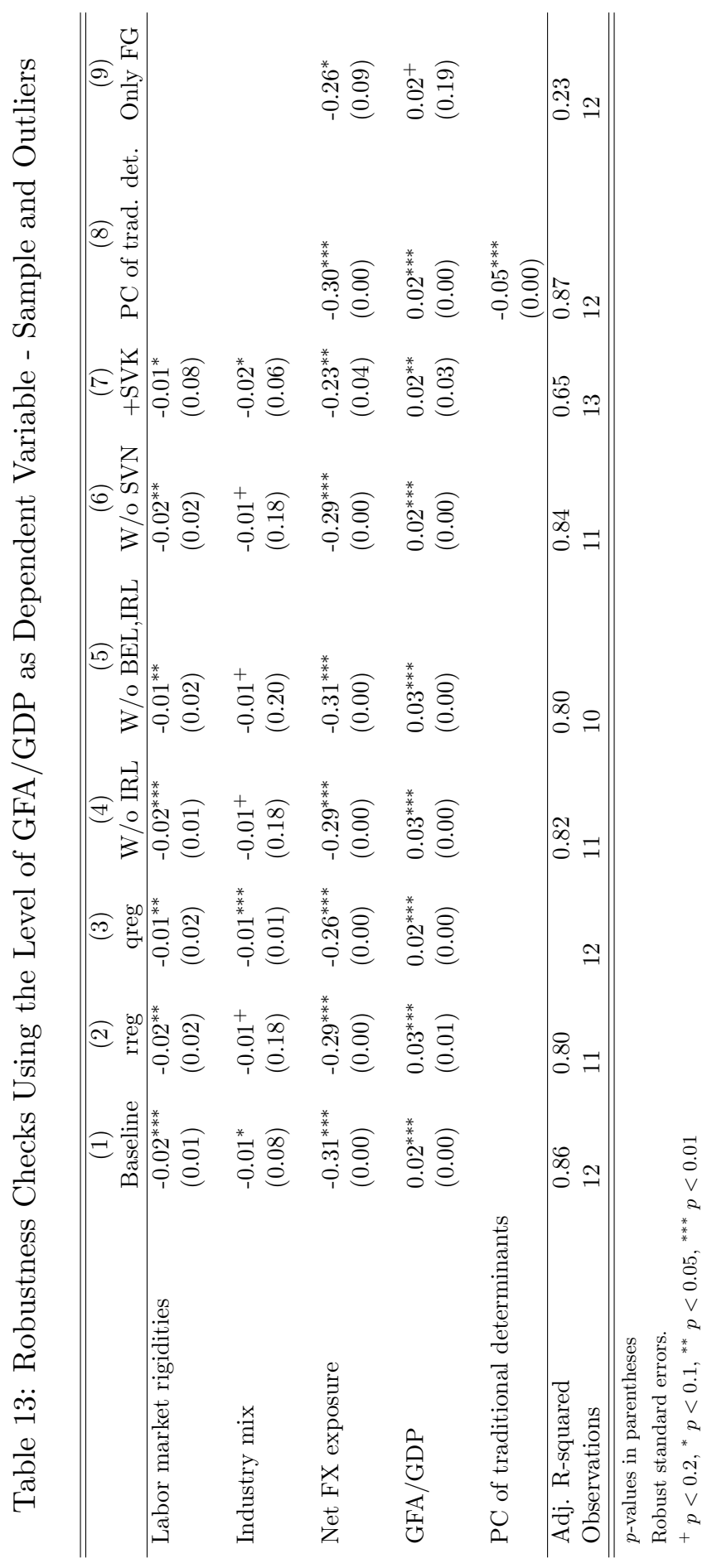




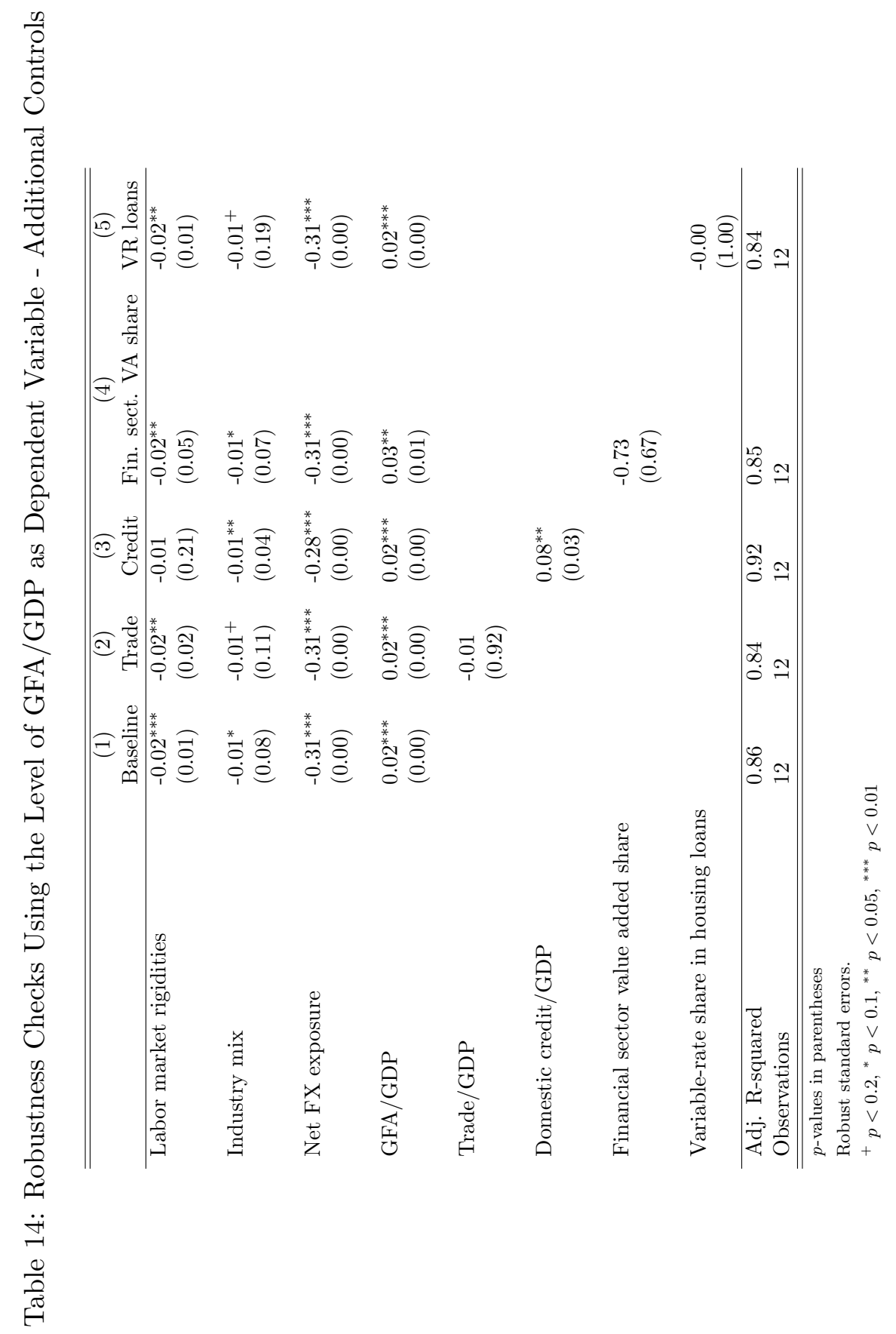




\section{F Figures}

Figure 1: GFA/GDP and Net Foreign Currency Exposure

Change between 1999 and 2009

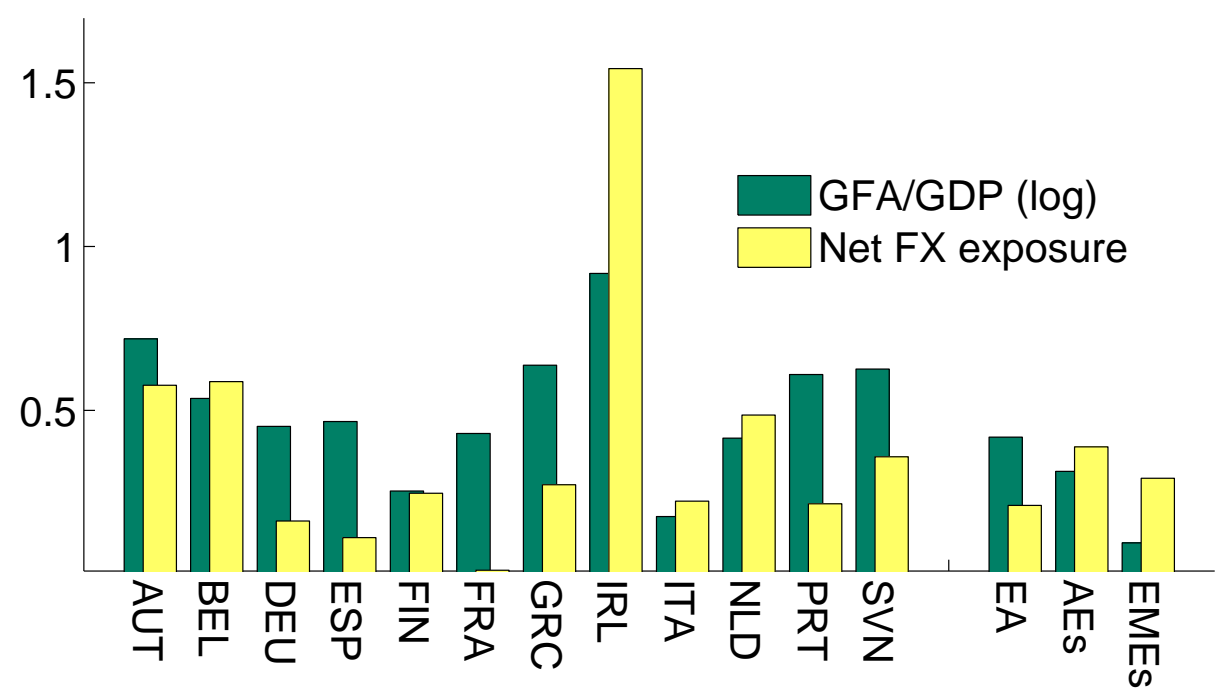

Values in 2009

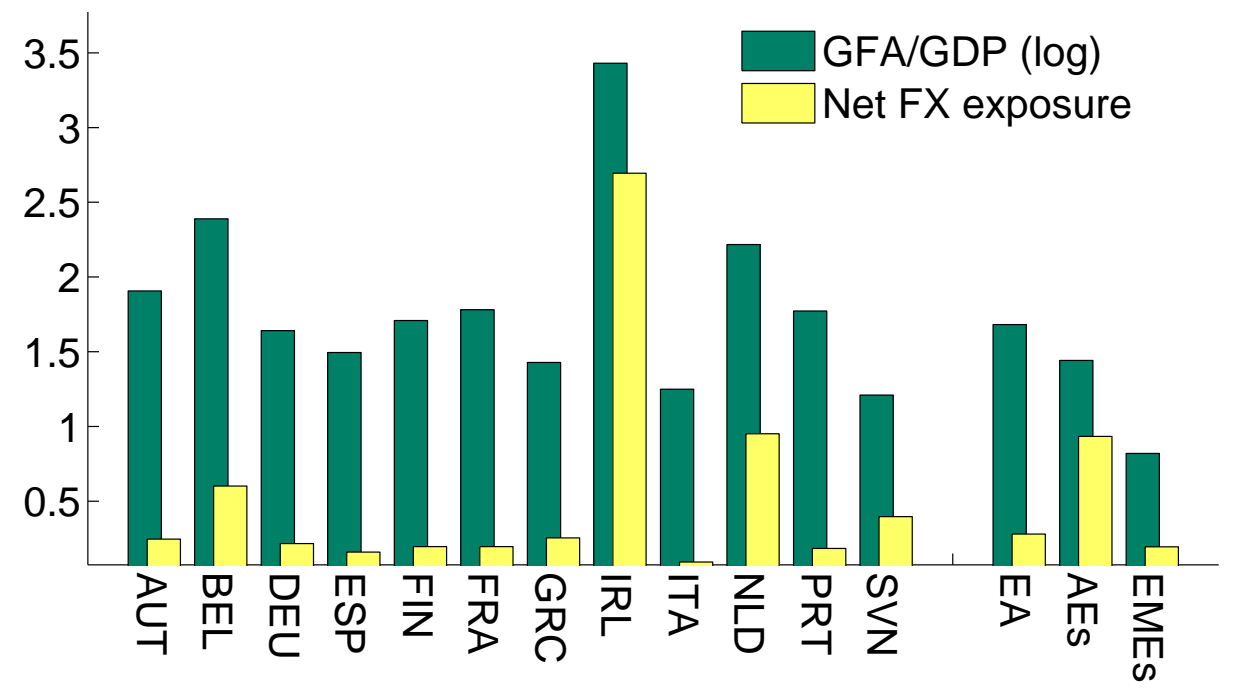

Note: The top panel shows the change in the gross foreign asset and liability position relative to GDP as well as the net foreign currency exposure of the economies in our sample. The bottom panel shows the corresponding averages over the sample period. The advanced economies exclude the euro area and the US, and emerging market economies exclude China. The country aggregates are GDP-weighted averages. 
Figure 2: Euro Area Monetary Policy Shock: Trough Response of Real GDP

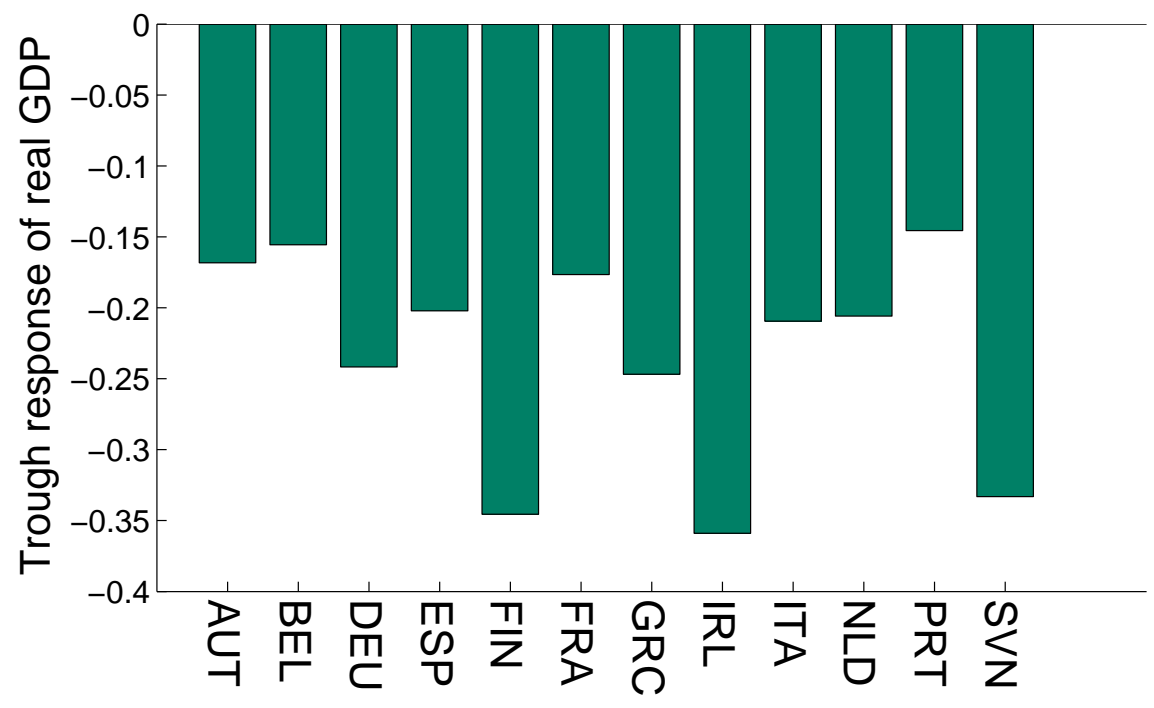

Note: The figure displays the trough responses of real GDP to a 100 basis points contractionary monetary policy shock in the euro area. The vertical axis depicts deviations from the baseline in percent. 
Figure 3: Scatter Plots for Gross Foreign Asset/Liability Positions, Net Foreign Currency Exposures and the Trough Responses of Real GDP
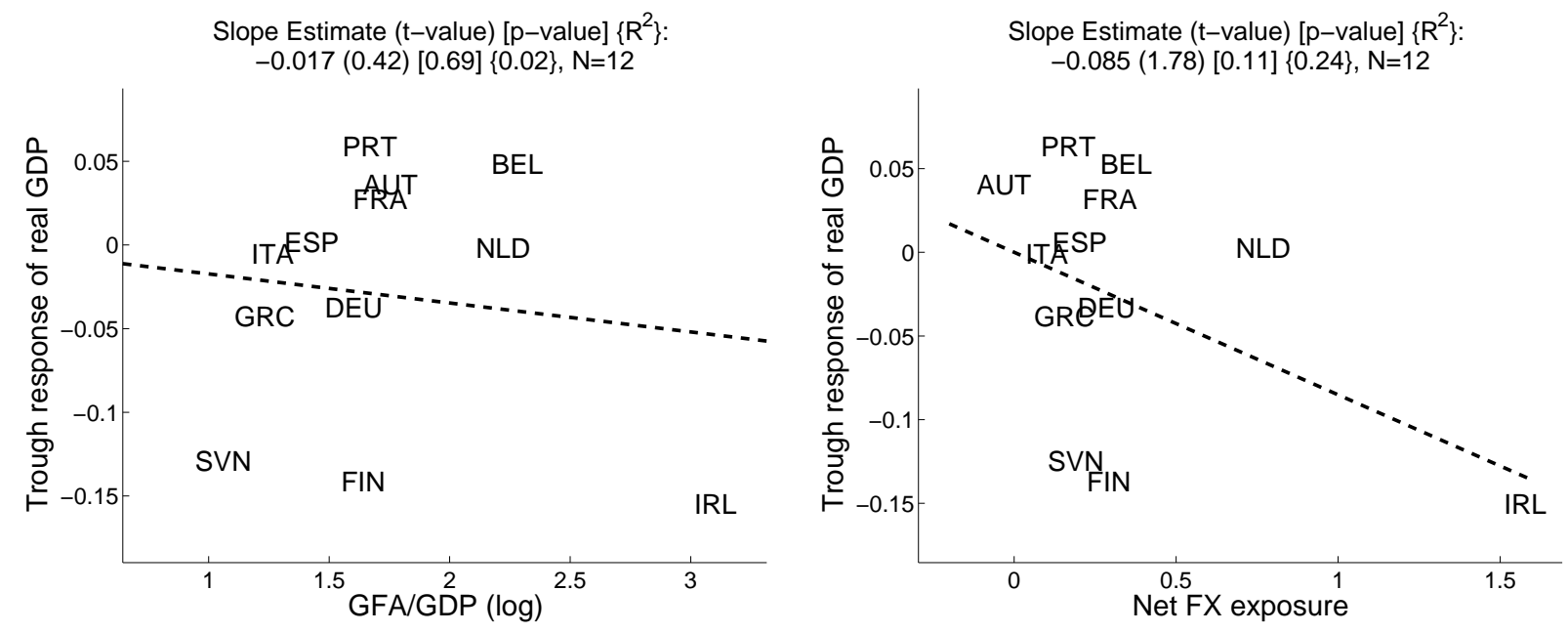

Note: The figure displays scatter plots between $\mathrm{gfal}_{i}, n f x_{i}$ and the trough responses of real GDP to a contractionary monetary policy shock. The trough responses are demeaned. 


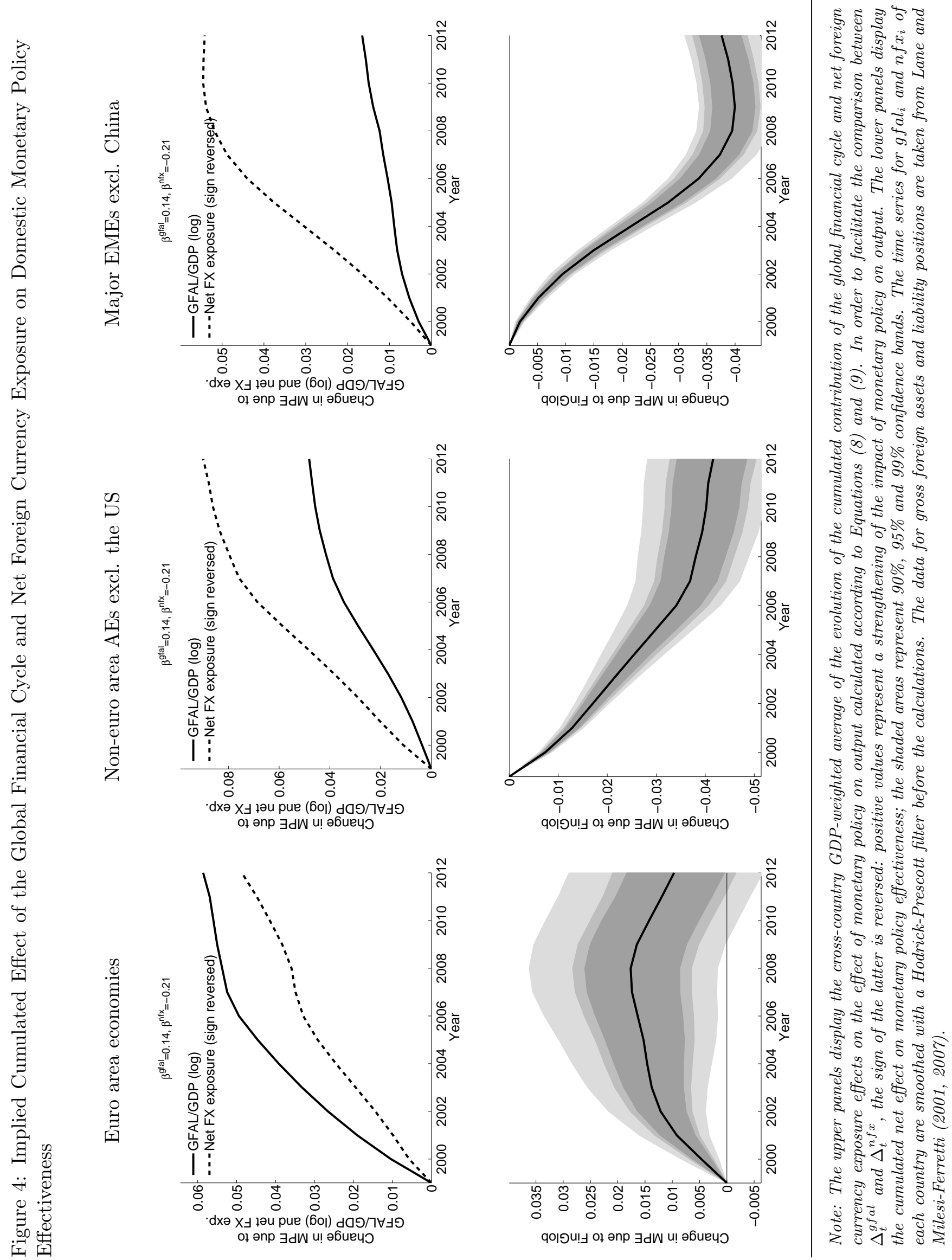


Figure 5: Change in Domestic Monetary Policy Effectiveness due to the Global Financial Cycle and Net Foreign Currency Exposure Effects

Euro area economies
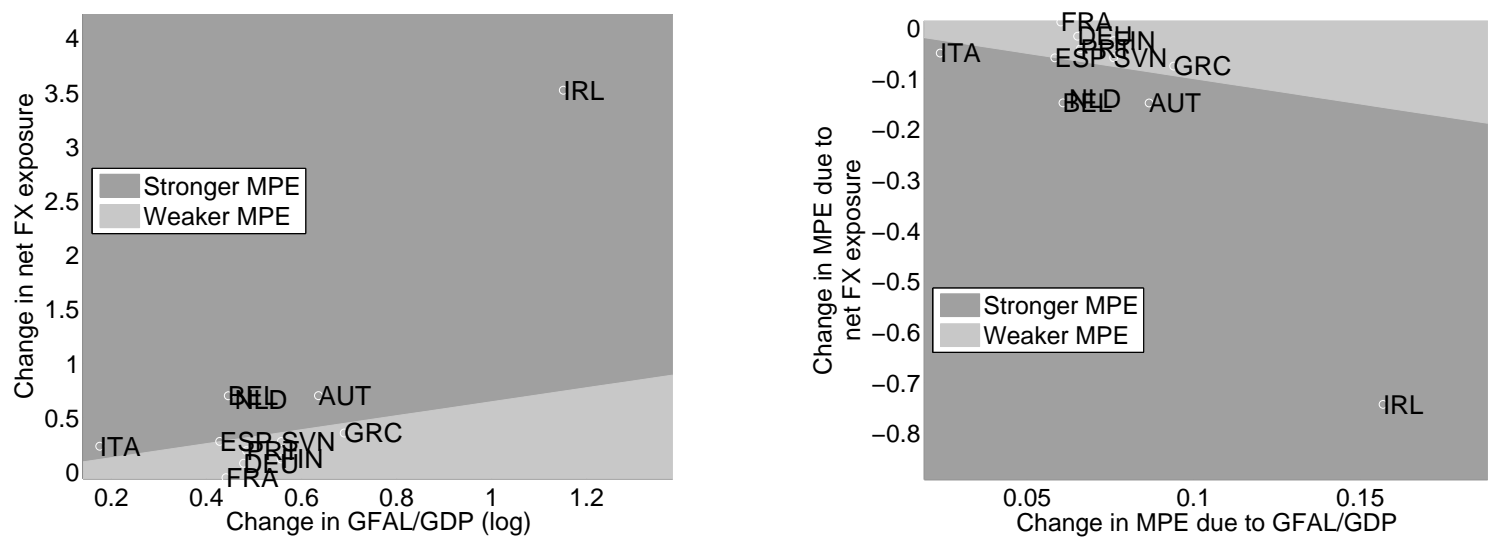

Non-euro area AEs excl. the US
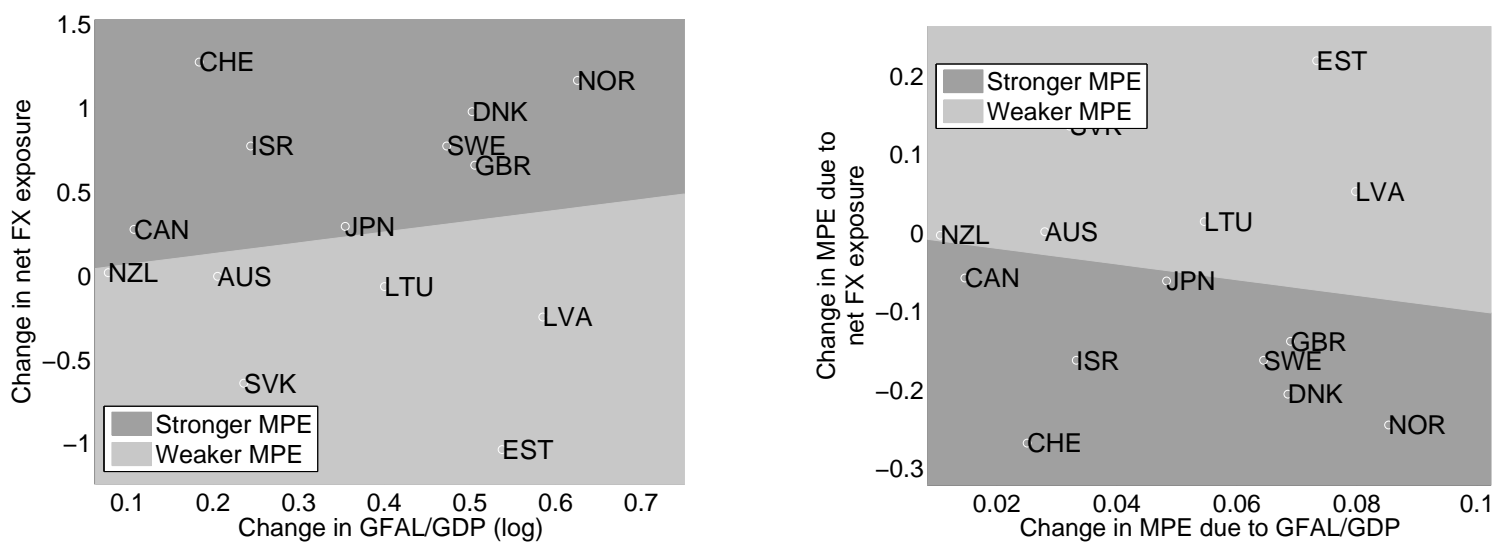

Major EMEs excl. China
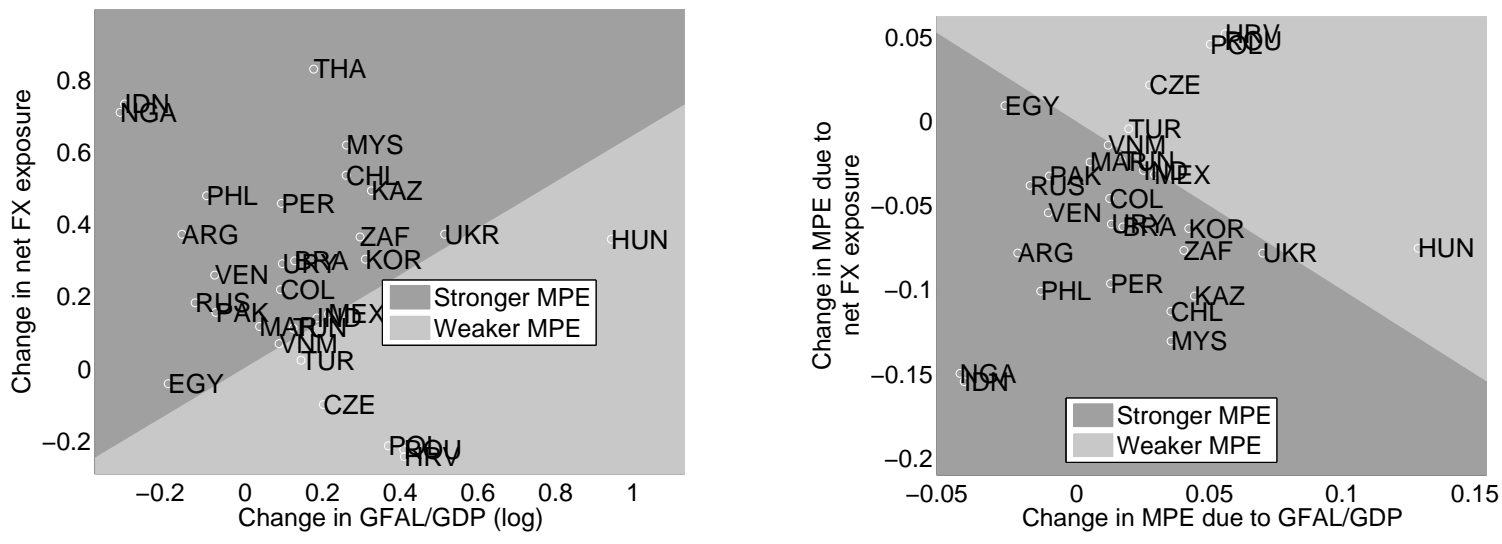

Note: The left-hand side panels shows the relationship between changes in gfal $_{i}$ and $n f x_{i}$ during 1999-2012 in the data; the shaded areas indicate the combinations of changes in $\mathrm{gfal}_{i}$ and $n f x_{i}$ which give rise to a stronger/weaker effect of monetary policy on output given the estimates $\widehat{\beta}^{g f a l}$ and $\widehat{\beta}^{n f x}$ in Equation (7). The right-hand side panels display the change in the impact of monetary policy on output during 1999-2012 that is due to the global financial cycle and net foreign currency exposure effects; the shaded areas indicate whether the former effect outweighs the latter and vice versa. 
Figure 6: Implied Cumulated Effect of the Global Financial Cycle and Net Foreign Currency Exposure Effects on Domestic Monetary Policy Effectiveness for 1990 to 2012

Non-euro area AEs excl. the US

$$
\beta^{\text {gfal }}=0.14, \beta^{\text {nfx }}=-0.21
$$
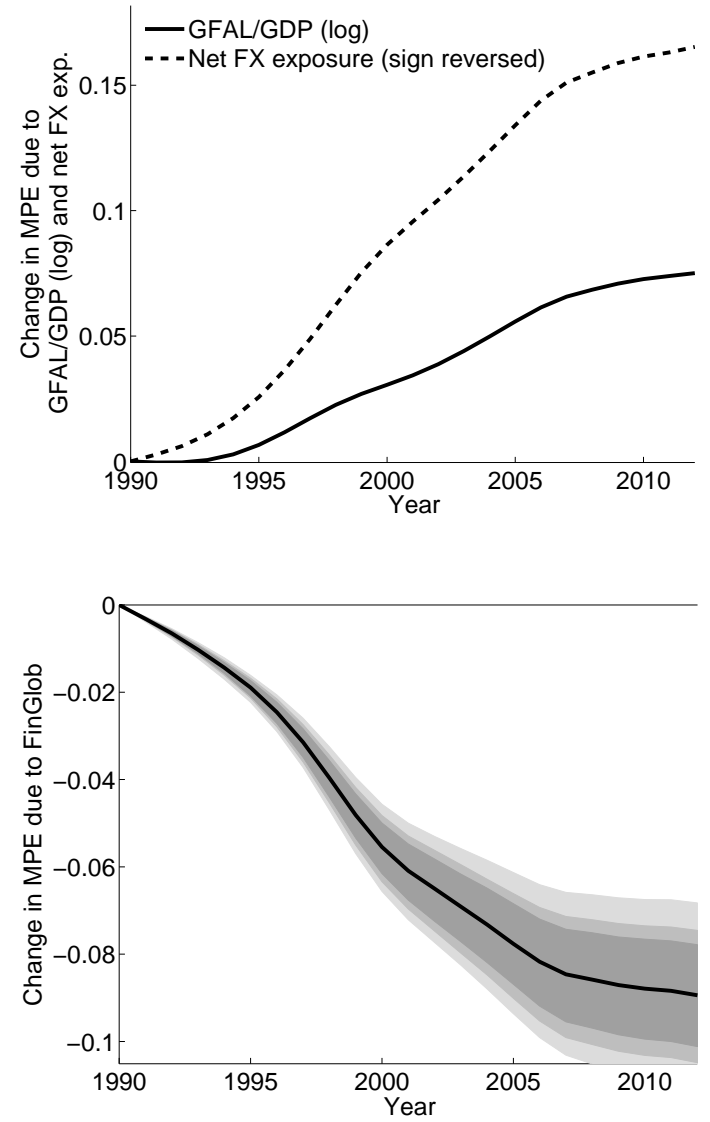

Major EMEs excl. China
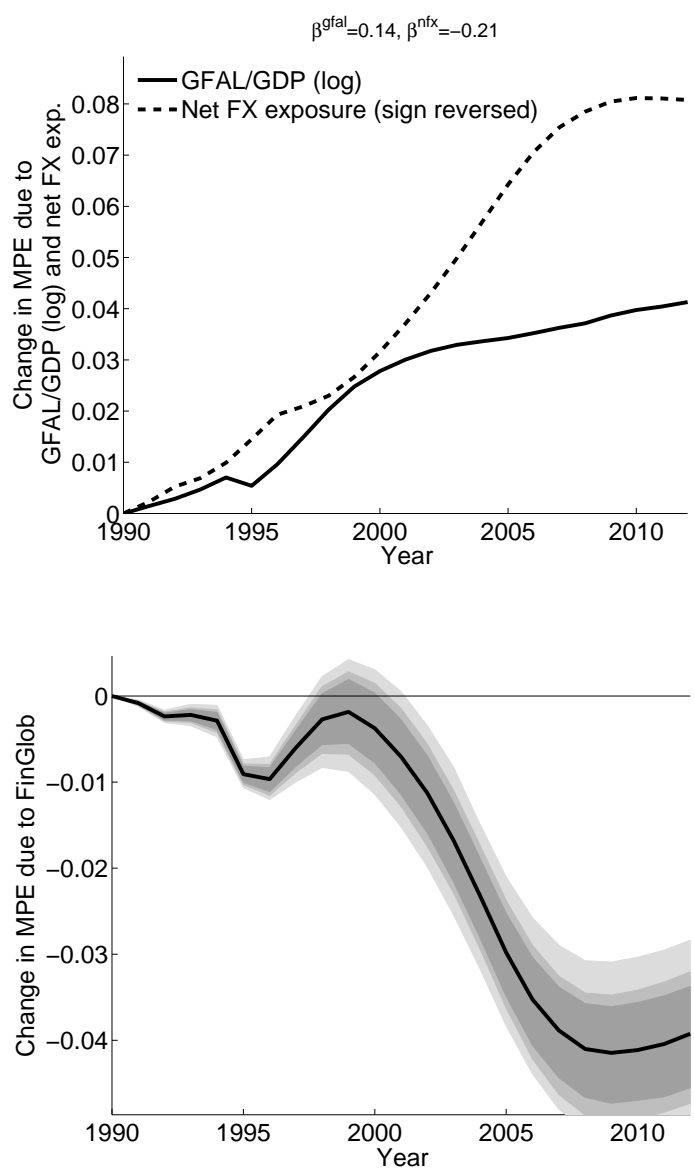

Note: See the note to Figure 4. 
Figure 7: Maximum Responses of the Euro Exchange Rate to a Contractionary Domestic Monetary Policy Shock

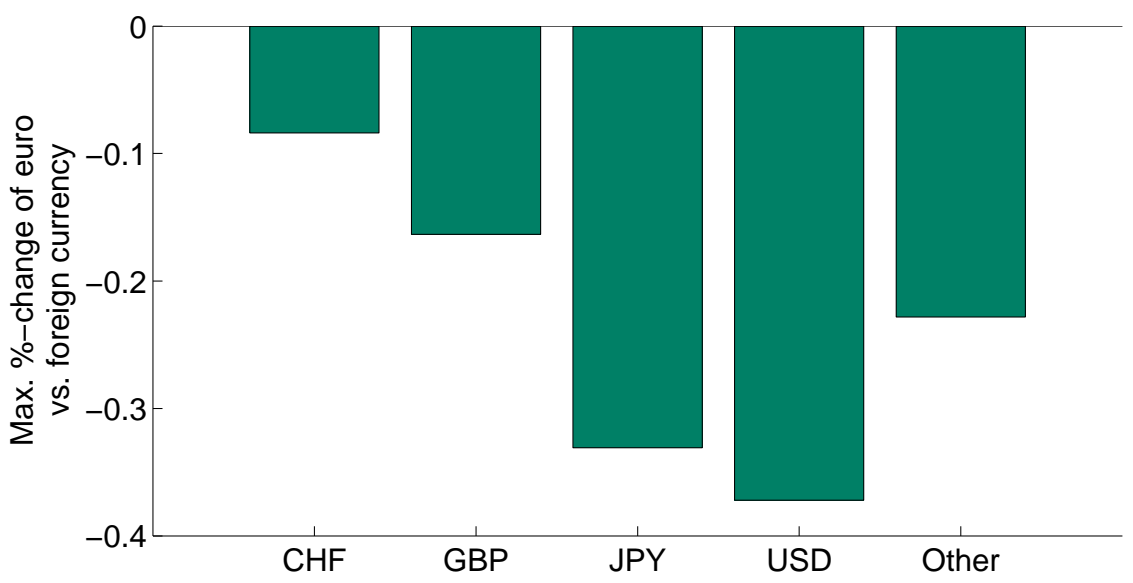

Note: The figure displays the maximum appreciation of the euro vis-à-vis other currencies in response to a 100 basis points contractionary euro area monetary policy shock. The exchange rate is expressed in terms of units of domestic currency relative to one unit of foreign currency. 


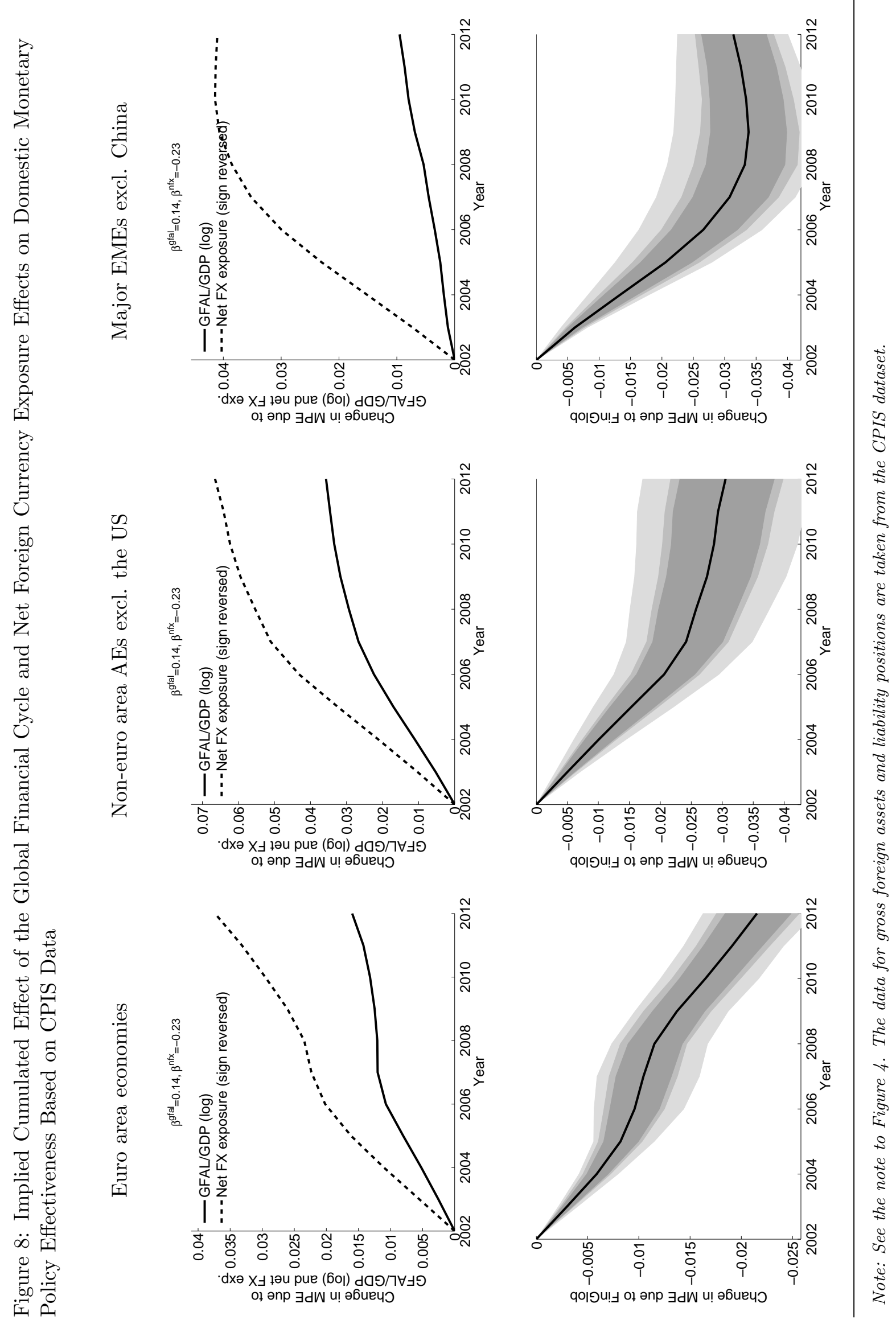



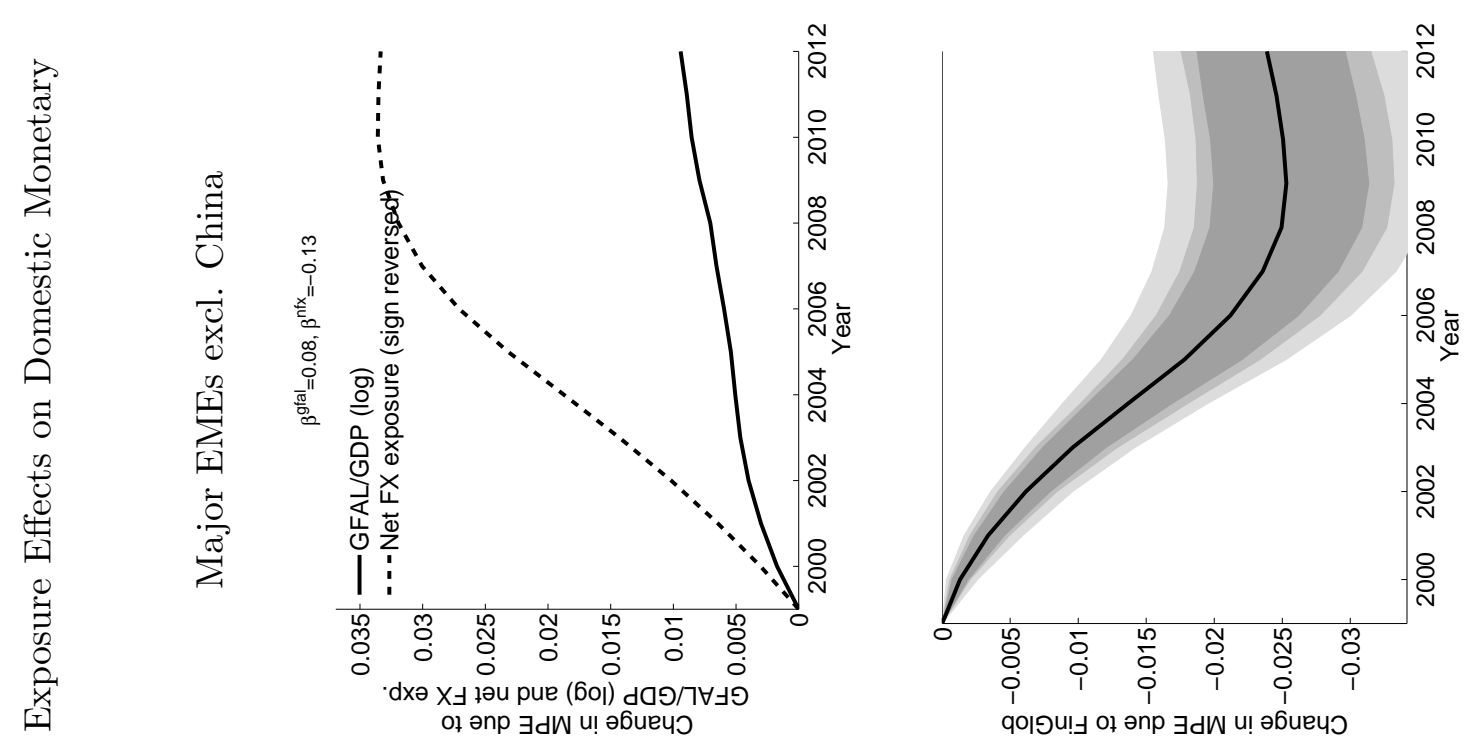

苞
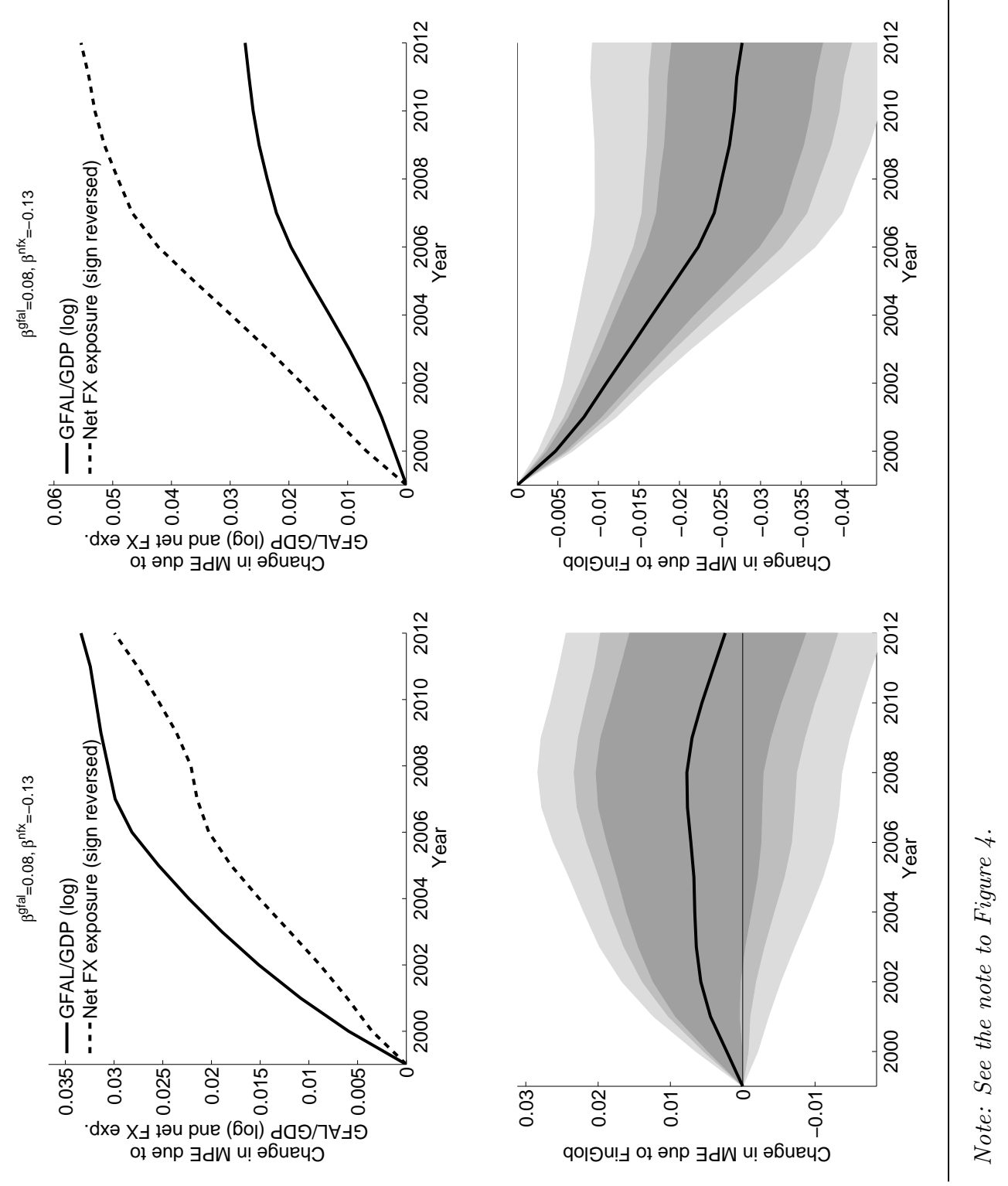

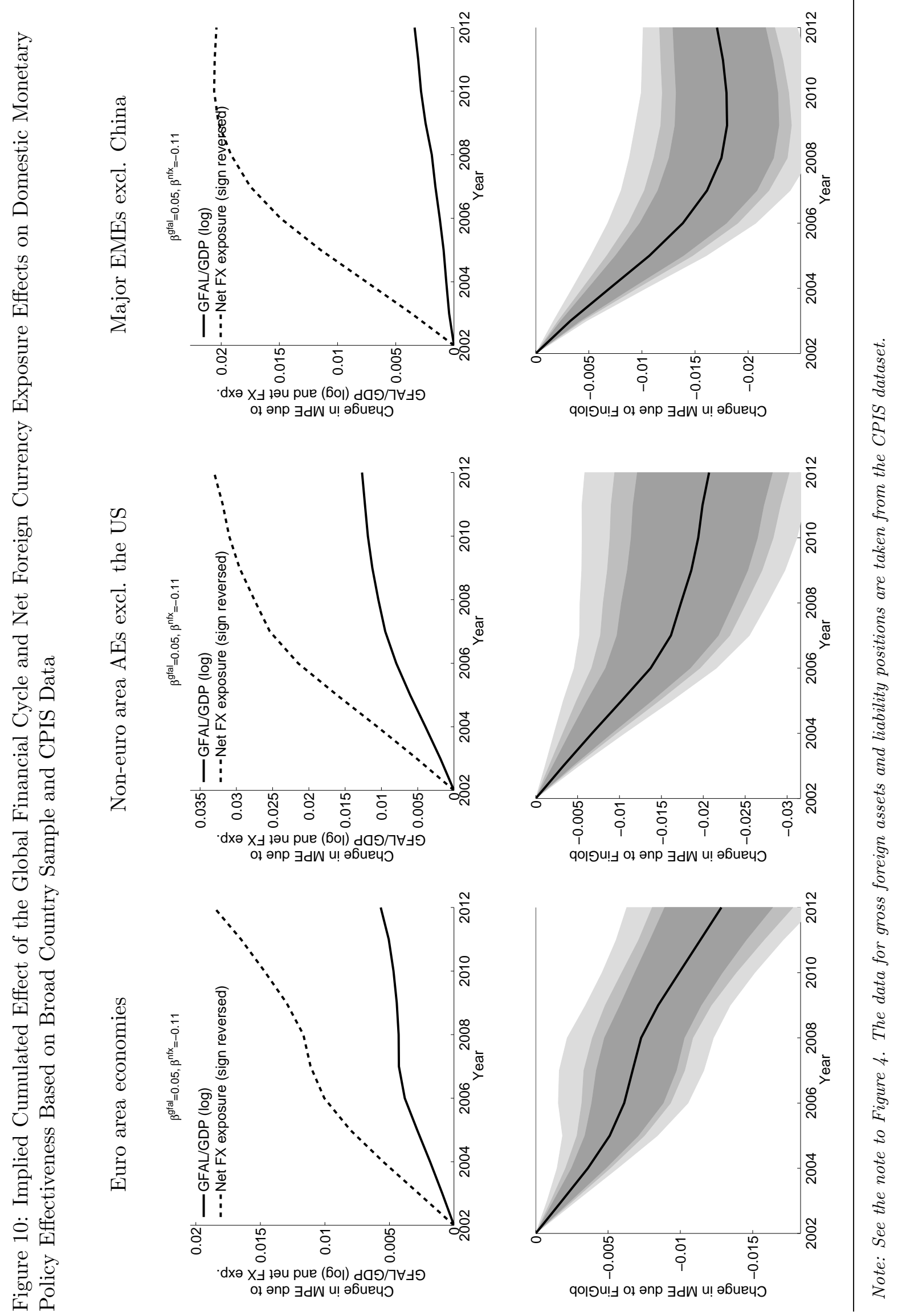
Figure 11: Implied Cumulated Effect of the Global Financial Cycle and Net Foreign Currency Exposure Effects on Domestic Monetary Policy Effectiveness across Robustness Checks
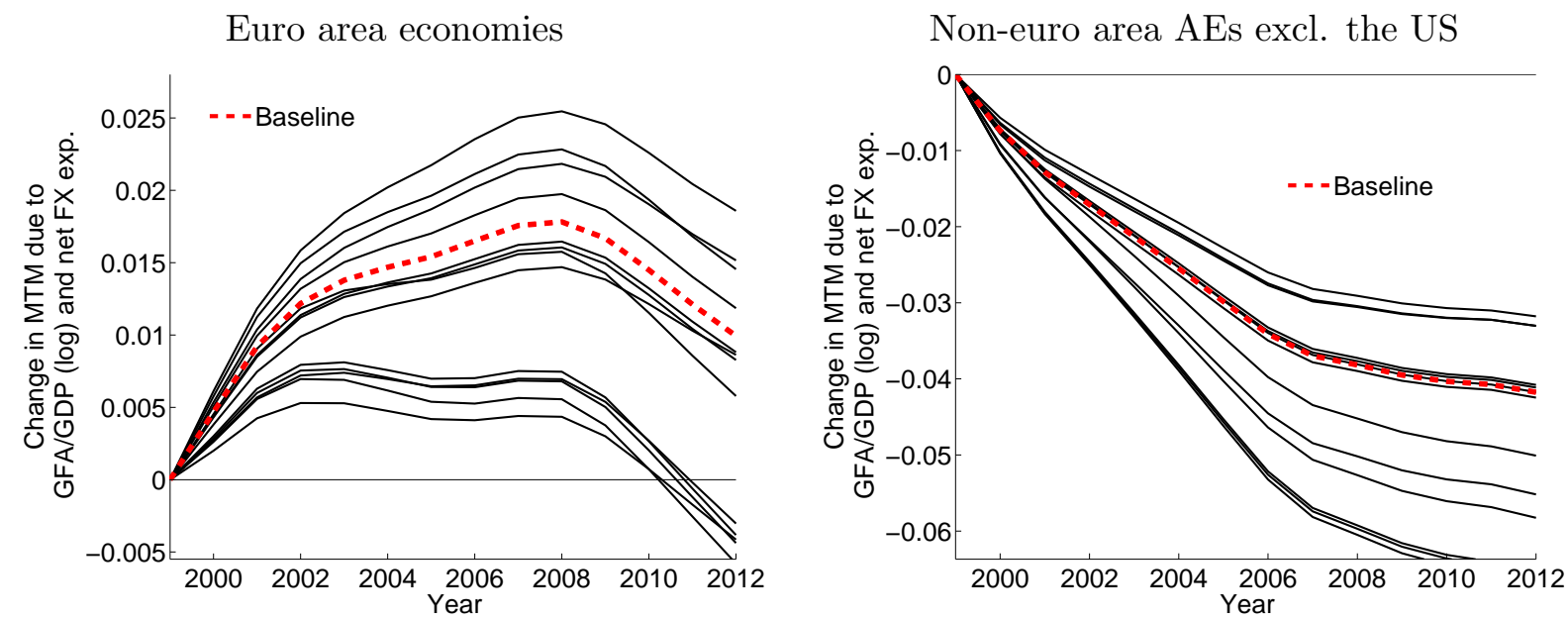

Major EMEs excl. China

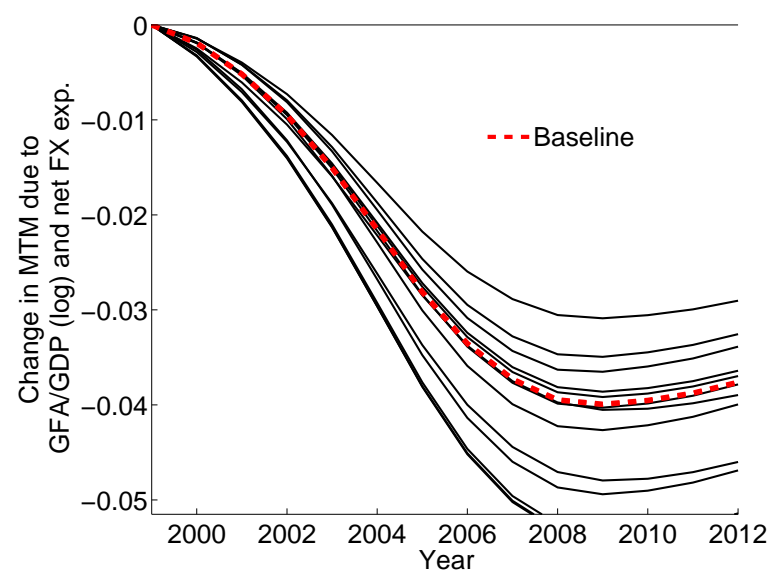

Note: The figure displays the cross-country GDP-weighted average of the evolution of the cumulated contribution of the global financial cycle and the net foreign currency exposure effects on domestic monetary policy transmission calculated according to Equations (8) and (9) across various robustness checks reported in Section 5.3. The red dashed lines represent the baseline results from Figure 4. The data for gross foreign assets and liability positions are taken from Lane and Milesi-Ferretti (2001, 2007). 